WOJCIECH BęBEN

Uniwersytet Gdański

\title{
Tradycyjna kultura rdzennych ludów Australii i Oceanii: perspektywa porównawcza
}

$\mathrm{O}$ bszar nazywany przez geografów Australią i Oceanią jest najrozleglejszym kontynentem świata. Trudno go jednak porównywać z innymi kontynentami, lądami o zwartych kształtach oraz wyraźnych konturach. Australia i Oceania stanowi raczej konglomerat mniejszych i większych lądów swobodnie rozrzuconych po olbrzymiej powierzchni Oceanu Spokojnego. Można by rzec, że to właśnie ten ocean, od którego pochodzi nazwa kontynentu, odcisnął piętno na tradycyjnej kulturze rdzennych mieszkańców tego regionu. Ale to nieprawda całe obszary Australii, jak również interior Nowej Gwinei, stanowiły mozaikę kultur typowo lądowych, które z morzem nie miały żadnego kontaktu. W istocie obszar kulturowy Australii i Oceanii składa się z kilku osobnych podkultur, w niewielkim tylko stopniu wchodzących ze sobą w relacje, nietworzących też, przynajmniej w dużej skali, wartości syntetycznych.

Mimo to w opracowaniach, także tych o naukowym charakterze, często używa się terminu „kultura”, względnie „sztuka Australii i Oceanii” (oczywiście chodzi tu o kulturę i sztukę tradycyjną). Czy jest to tylko efektem nałożenia prostej, geograficznej kalki na zróżnicowaną rzeczywistość, która w innym wypadku w ogóle by nie miała wspólnego kulturowego mianownika? Chyba jednak nie do końca. Wydaje się, że mimo wymienionych wyżej zastrzeżeń nie można owej taksonomicznej praktyki oceniać jednoznacznie negatywnie. Ten artykuł jest próbą odpowiedzi na pytanie, w jaki sposób można mówić o wspólnych cechach kultury (a kultury materialnej w szczególności) rdzennych ludów Australii i Oceanii ${ }^{1}$.

\footnotetext{
${ }^{1}$ Podstawowym źródłem wiedzy dla tego tekstu jest zarówno moja wiedza terenowa pochodząca z 30 lat badań etnograficznych na Nowej Gwinei, Melanezji i w Australii (zob. Bęben
} 


\section{Wprowadzenie}

Pod względem typologii kultur tradycyjnych obszar Australii i Oceanii można podzielić na trzy zasadnicze regiony:

1. Australia - z archaicznymi kulturami zbierackimi i łowieckimi.

2. Nowa Gwinea - reprezentująca wczesny etap kultur rolniczych.

3. Austronezja, czyli Wschodnie Wyspy - typowy przykład kultur ludów morza. W jej skład wchodzą zarówno niewielkie powierzchnią archipelagi, jak i rozległa obszarem Nowa Zelandia.

Badania antropologów, paleontologów i genetyków prowadzą do zgodnego wniosku, że chronologia zasiedlania przez człowieka tych trzech wielkich obszarów odpowiada stopniowi rozwoju materialnej kultury ludów zamieszkujących poszczególne obszary. Najwcześniej została zasiedlona Australia, po niej Nowa Gwinea, na końcu zaś morskie obszary mniejszych oraz większych wysp.

Człowiek rozumny, Homo sapiens sapiens, był pierwszą istotą ludzką, która zobaczyła Australię. Ląd australijski nie był wtedy jeszcze oddzielony od Azji sporym odcinkiem Oceanu Indyjskiego - ludzie pierwotni mogli się tutaj dostać przez szereg cieśnin oddzielających wyspę od wyspy (przedłużenie dzisiejszego łańcucha wysp Indonezji). Stało się to w okresie górnego plejstocenu, czyli około 50 tys. lat temu. Pierwsi Australijczycy wykazywali wiele cech człowieka pierwotnego, a wyrażając się precyzyjnie: ludzi z podgatunków reprezentujących wcześniejsze niż Homo sapiens sapiens, zatem w rozwojowej perspektywie ewolucji bardziej archaiczne fazy istnienia. Budowa części twarzowych czaszek z tego okresu, odnalezionych na stanowiskach archeologicznych, wykazuje duże podobieństwa z odpowiednimi częściami czaszek neandertalczyków znalezionych w Europie (Paluch 1983).

Przybysze pokrewni Negrytom, którzy w wielkiej wędrówce na wschód pozostawili ślady, do dziś identyfikowalne w postaci szczątkowych grup etnicznych (Andamany i Nikobary, Sumatra, Wyspy Filipińskie, Malaje), zasiedlili najpierw wybrzeża. Ich wędrówka wokół morskiego brzegu Australii trwała kilka tysięcy lat ${ }^{2}$. Dopiero w drugiej kolejności, gdy całe wybrzeże było już zajęte przez człowieka, kolejne pokolenia zdobywców zapuściły się w głąb lądu.

Kolejną, drugą falę osiedleńczą, reprezentowali Murrayanie (20-25 tys. lat temu), nazwani tak od rzeki Murray, w której basenie znajdujemy dziś pozostałości archeologiczne ich pobytu. Murrayanie różnili się rasowo od Negrytów, mieli

2004, 2012, 2015, 2016, 2019), jak i bogata literatura przedmiotu (odnośnie do historii i prahistorii zob. np. Bowdler 1977; Murray, Leonards 1988; Borofsky 2000; Fischer 2002; Hiscock 2008; odnośnie do zróżnicowania językowego zob. np. Foley 2002; Ross 2005; Kjellgren 2007; Palmer 2018; odnośnie do sztuki i kultury materialnej zob. np. Barrow 1989; Mountford 1989; Caruana 1993; Meyer 1995; Morphy 1998; Bolton i in. 2013; Brunt i in. 2013). Dużą pomocą były też prace polskich badaczy Australii i Oceanii (zob. np. Posern-Zieliński 1972; Godlewski, Paluch 1979; Paluch 1983; Szyjewski 1998; Rosiński 2001; Bakke 2004; Bednarowicz 2004).

${ }^{2}$ Hipotezę Sandry Bowdler, która jako pierwsza przedstawiła model pierwotnego zasiedlenia Australii wzdłuż wybrzeży (1977), potwierdziły opublikowane w 2011 roku wyniki badań genetycznych. 
jaśniejszą skórę i proste włosy. Narzędzia, które pozostawili, wykazują wyższy poziom technologii od surowych kamiennych narzędzi, którymi posługiwali się Negryci.

Trzecia fala zaludnienia Australii przypadła Karpentarianom ${ }^{3}$ (nazwa od zatoki Karpentaria na północy kontynentu). Przybyli tutaj około 15-20 tys. lat temu, spychając ludność wcześniej żyjącą na suche obszary australijskiego wnętrza. Stopniowe zlewanie się Murrayan i Karpentarian w jedną grupę dało początek obecnej populacji Aborygenów.

Pierwsi Australijczycy byli nomadami, przemieszczali się w zależności od pór roku z miejsca na miejsce, ekstensywnie wyzyskując skromne zasoby naturalne australijskiej ziemi. Nie budowali domostw, w porze wilgotnej stawiali jedynie szałasy. Żyjąc na poziomie pierwotnej wspólnoty, w zasadzie nie znali własności prywatnej - olbrzymia większość wytworzonych przedmiotów służyła tam nie jednostce, ale nomadycznej wspólnocie. Osobisty charakter miały tam najczęściej - co znamienne - proste dziecięce zabawki, zrobione z drewna, kości, muszli bądź kamienia. Wspólnota aborygeńska nie znała też specjalizacji. Każdy członek nomadycznej hordy musiał - $w$ toku rodzimej edukacji - nabyć porównywalny z innymi zestaw niezbędnych, praktycznych umiejętności. Brak specjalizacji owocował też przyjęciem konkretnego modelu społecznego, w zasadzie pozbawionego hierarchii, a już na pewno hierarchii dziedzicznej.

Pewne funkcje naczelników pełnili tam jedynie ludzie starsi ${ }^{4}$. Ta wyższość nie była jednak nigdy usankcjonowana hierarchizacją układów społecznych jak na pozostałych obszarach świata, gdzie kultury łowieckie przeradzały się w cywilizacje rolnicze. Respekt, jakim otaczano najstarszego członka hordy, wynikał z podejścia praktycznego: skoro ten człowiek był w stanie przeżyć odpowiednio długo w warunkach naturalnych niesprzyjających ludziom, oznacza to, że posiada mądrość predestynującą go do doradzania (nie przewodzenia!) grupie. Pozycja starszych w hordzie aborygeńskiej i ich społeczna kontrola miały więc charakter praktyczny i spontaniczny (patrz też: Murray, Leonards 1988; Hiscock 2008).

Niewiele młodszą genezę ma kolonizacja Nowej Gwinei (około 45 tys. lat temu). Papuasi przybyli tutaj tą samą drogą co przodkowie Aborygenów do Australii - od północnego-zachodu, przez cieśniny plejstoceńskiego subkontynentu Sunda (dzisiejsza Indonezja). Osiedlali się w pobliżu ujść rzek, z czasem ekspandując $w$ górę ich biegu. Budowali domy z drewna i liści palmowych, nieraz obszerne, służące za mieszkanie wielu rodzinom nuklearnym. W drugim etapie osiedlenia Papuasi zaludnili górzyste wyżyny środka wyspy (patrz też: Foley 1986; Palmer 2018).

Zarówno przodkowie Aborygenów, jak i Papuasów - aczkolwiek wędrowali wzdłuż brzegu morskiego, względnie brzegu większej rzeki - nie byli ludami morskimi. W swoich migracjach zasadniczo nie posługiwali się czółnami ani łodziami; jeżeli z konieczności przemieszczali się drogą wodną, używali prostych

\footnotetext{
${ }^{3}$ Być może genetycznie pokrewnym współczesnym Weddom z Cejlonu.

${ }^{4}$ Ich pozycję porównuje Andrzej Paluch (1983: 41) do greckiej gerontokracji.
} 
tratew. Inaczej ma się rzecz z Austronezyjczykami. Ten lud, dysponując odpornymi na sztormy czółnami, w ciągu stosunkowo niedługiego czasu był w stanie zasiedlić olbrzymie obszary Melanezji, Polinezji i Mikronezji, włącznie z najdalej leżącymi archipelagami.

Przedostając się z terenu kontynentalnych Chin, przodkowie Austronezyjczyków około 3 tys. lat p.n.e. zasiedlili Tajwan. Stamtąd około 2 tys. lat p.n.e. przepłynęli na archipelag Filipin. Z Filipin około 1,5 tys. lat p.n.e. skolonizowali indonezyjską wyspę Sulawesi (dawna nazwa: Celebes). Stamtąd nastąpiła niebawem morska kolonizacja w kilku kierunkach. Posuwając się łańcuchem wysp indonezyjskich na zachód, Austronezyjczycy około 500 roku p.n.e. dotarli do zachodnich krańców Sumatry. Tysiąc lat później, około 500 roku, inna grupa żeglarzy przepłynęła Ocean Indyjski i zatrzymała się u wybrzeży Madagaskaru. Morscy wędrowcy, którzy wyruszyli w przeciwnym, zachodnim kierunku, skolonizowali Nowe Hebrydy (Vanuatu) i Fidżi, tworząc tam stosunkowo wysoko rozwiniętą kulturę Lapita (1400-800 roku p.n.e.). Jej przedstawiciele uprawiali taro i jamy, pozyskiwali owoce drzewa chlebowego, hodowali świnie i kury. Wytwarzali czerwoną ceramikę stemplowaną i posługiwali się narzędziami z obsydianu. Potomkowie tej fali przybyszów stanowią dziś rdzeń ludów Polinezji.

Posuwając się na wschód, austronezyjscy żeglarze zasiedlali stopniowo archipelagi małych wysp rozrzuconych na olbrzymim akwenie Pacyfiku. Około 1,5 tys. lat p.n.e. skolonizowali w ten sposób zachodnią część Mikronezji, od około 500 roku p.n.e. do I wieku n.e. zasiedlili część wschodnią. W latach 300-800 opanowano polinezyjskie Hawaje, 600-1250 zasiedlono Tuamotu i sąsiednie archipelagi. Około 1300 roku opanowano Nową Zelandię. Mniej więcej w tym samym czasie łodzie Austronezyjczyków dotarły do Wyspy Wielkanocnej (Rapa Nui), położonej niedaleko wybrzeży Ameryki Południowej (zob. też: Posern-Zieliński 1972; Godlewski, Paluch 1979; Borofsky 2000; Rosiński 2001; Fischer 2002).

W odróżnieniu od mieszkańców Australii oraz Nowej Gwinei Austronezyjczycy reprezentowali spójną i jednolitą grupę etniczną. Wywodzili się z jednego etnosu (przybyłego z południowych Chin ${ }^{5}$ ), mówili tym samym językiem, który nawet po oceanicznych migracjach $\mathrm{w}$ różnych kierunkach nie zróżnicował się na tyle, aby zrodzone zeń lokalne dialekty miały stanowić barierę wzajemnego porozumienia. Pod względem społeczno-kulturowym Austronezyjczycy stanowili społeczność typowo plemienną6: skupiali się wokół bohaterów (w tym wypadku: przywódców morskich wypraw), którzy utrwaleni w opowieściach, z biegiem pokoleń nabierali cech boskich, wchodząc do lokalnej mitologii. Także ich sztuka, z pełnopostaciowymi figurami z drewna, nawiązywała do historii morskiego podboju i zasiedlenia.

\footnotetext{
${ }^{5}$ W 1932 roku austriacki antropolog Robert von Heine-Geldern zwrócił uwagę na kształt ostrza typowego austronezyjskiego topora, który był podobny do chińskiego. Takiej broni używano w prowincji Junnan (Fraser 1976: 117-118).

${ }^{6}$ Autor używa terminu „plemię" lub „plemienny” w dwóch znaczeniach. W pierwszym jest ono rozumiane jako synonim ludu jako odrębnej grupy etnicznej lub grupy kulturowo-językowej. $\mathrm{W}$ drugim znaczeniu plemię jest pojmowane jako rodzaj organizacji społeczno-politycznej o wyraźnie wyodrębnionych segmentach społeczno-politycznych (przyp. red.).
} 
Mimo obecności tego kluczowego elementu w kulturze materialnej Melanezji, Mikronezji i Polinezji, ukształtowane z biegiem wieków lokalne estetyki różnią się od siebie w sposób znaczący. „Nie istnieje coś takiego jak «styl polinezyjski» - twierdzi znawca tematu, Douglas Fraser (1976: 119-221) - występuje raczej obfitość stylów, mających różne cechy w zależności od okresu historycznego". Fraser zaznacza jednak, że wszystkie mają wspólne pochodzenie, gdyż wywodzą się z Azji.

\section{Australia}

Gdy prześledzimy na mapie trasę morskich wędrówek Austronezyjczyków, uderzy nas pewna prawidłowość: cała ta wielka migracja szerokim łukiem omija aborygeńską Australię i jedynie powierzchownie dotyka papuaską Nową Gwineę. W wypadku tej ostatniej brak wyraźnych postępów austronezyjskiego osadnictwa w głębi lądu można wytłumaczyć niekorzystnymi warunkami terenowymi (bagniste, malaryczne i gęsto zarośnięte estuaria nie dawały żeglarzom dostępu do interioru), jak również wojowniczym usposobieniem Papuasów. Trudno takie wyjaśnienia zastosować do Australii, która przynajmniej na odcinku północno-wschodnim (Queensland, półwysep Jork) posiada warunki dogodne do osiedlenia grup przybyłych łodziami. Potencjał militarny Aborygenów, rodem z paleolitu, też nie mógł tutaj stanowić przeszkody dla ewentualnego podboju. Ta zagadka czeka na wyjaśnienie.

Obszar Australii dzieli się na trzy krainy fizjograficzne: Wielkie Góry Wododziałowe, łańcuch niezbyt wysokich szczytów ciągnący się wzdłuż wybrzeża Pacyfiku, Równinę Środkową ${ }^{7}$ oraz Wielki Płaskowyż Zachodni, dochodzący do Oceanu Indyjskiego. Dwie ostatnie krainy, stanowiące rozległe, suche i rzadko zaludnione obszary, w mniemaniu wielu osób spoza Australii stały się symbolem tutejszego krajobrazu. Jednak fizjografia tego kontynentu jest bardziej zróżnicowana, niż wynikałoby to z popularnych opisów.

Panoramę krajobrazów Australii zacznijmy od opisu Wielkich Gór Wododziałowych. W najwyższej partii tych gór, na południu, granitowe szczyty wznoszą się do wysokości 2000 m n.p.m. (Góra Kościuszki w Alpach Australijskich liczy $2228 \mathrm{~m}$ ). Ich niższym, lecz bardziej malowniczym odcinkiem są leżące w pobliżu Sydney Góry Błękitne. Ich nazwa wzięła się od charakterystycznej mgiełki powstającej z oparów olejków eterycznych z kwitnących lasów eukaliptusowych, które pokrywają większą część tego obszaru. To stara formacja geologiczna zbudowana z piaskowca. Podczas trwającej miliony lat erozji i tworzenia skał ostańcowych powstały tutaj przepaście i kaniony, nierzadko o głębokości 700-800 m. Większa część pozostałych partii Gór Wododziałowych stanowi dość łagodne wzniesienia. Wysokość szczytów maleje wraz z ich wysunięciem ku północy. Najniższą partię tego łańcucha stanowi półwysep Jork, który zanurza

\footnotetext{
${ }^{7}$ W polskiej nomenklaturze geograficznej stosuje się nazwę Nizina Środkowoaustralijska.
} 
się w oceanie na wysokości Cieśniny Torresa, gdzie pagórkowate szczyty, zniżając się stopniowo, przybierają postać niewielkich wysepek. Na południowych antypodach Gór Wododziałowych kulminacją wzniesień jest wyspa Tasmania.

Południowa nasada Jorku, patrząc od strony Pacyfiku, jest jedynym w Australii miejscem występowania lasów tropikalnych. Stoki południowych partii Gór Wododziałowych porastają lasy eukaliptusowe lub figowe. Szerokimi dolinami spływają tam ku wschodowi rzeki, które nie wysychają w porze suchej - rzecz rzadka w Australii. Również rzeki kierujące się na zachód, ku pustynno-stepowemu sercu kontynentu, w swoim górnym biegu są ciekami stałymi ${ }^{8}$. Kraina ta charakteryzuje się umiarkowanym klimatem: deszcze padają tutaj stosunkowo często, zaś wahania temperatury są wyraziste - w zależności od pory roku. Krajobraz przypomina widoki znane z Europy.

Na wschód od łańcucha Gór Wododziałowych leży Równina Środkowa, płaska, z rzadka porośnięta eukaliptusami sawanna, której monotonny krajobraz urozmaicają jedynie widoki krętych korytarzy wysychających okresowo rzek. Klimat jest tu znacznie gorętszy niż w górach, a opady znacznie mniej obfite. Wschodnia część Równiny (Riverina) jest lepiej nawodniona i żyźniejsza; im dalej na zachód, tym okolica staje się suchsza.

Płaskowyż Zachodni zajmuje pozostałą część kontynentu - dwie trzecie obszaru Australii. Według pojęć geograficznych jest wyżyną: jego rozległa lądowa tarcza wznosi się na wysokość 300-600 m n.p.m. Na całym tym wielkim terytorium znajduje się kilka odizolowanych od siebie górskich wypiętrzeń: Góry MacDonnella i Góry Musgrave w centrum, Grzbiet Hamersleya na zachodzie, Grzbiet Darling na południowo-zachodnim krańcu, wzgórza Kimberley na północnym-zachodzie. Obszary płaskie zajmują pustynie i półpustynie. Jest to najmniej gościnna, najmniej sposobna do zbiorowego ludzkiego życia - zarówno w jego nomadycznym, jak i osadniczym wariancie - część Australii.

Pod względem klimatycznym cały kontynent należy do strefy tropikalnej i subtropikalnej. Za wyjątkiem Gór Wododziałowych oraz niektórych odcinków wybrzeża przeważa tutaj klimat suchy i gorący. Mało zróżnicowany pionowo teren nie stanowi przeszkody dla cyklicznych prądów powietrza. Od maja do października płynie przez równiny zachodni prąd niskiego ciśnienia, zaś od listopada do kwietnia gwałtowne zachodnie wiatry omiatają stoki wzniesień Wiktorii oraz wybrzeże Tasmanii. Najcieplejszym miesiącem jest tutaj styczeń, najzimniejszym lipiec. Średnia temperatura w porze letniej wynosi około $30^{\circ} \mathrm{C}$, w porze zimowej $10-15^{\circ} \mathrm{C}$. Przewaga miejsc suchych decyduje o małej średniej opadów, która w ogólnoaustralijskiej skali wynosi zaledwie $500 \mathrm{~mm}$ rocznie. Z tego też powodu Australia uważana jest za najbardziej pustynny spośród kontynentów, chociaż obszarów całkowicie pozbawionych roślinności jest tutaj stosunkowo niewiele.

\footnotetext{
${ }^{8}$ Spośród większych rzek jedynie Murray, największa rzeka kontynentu, jest akwenem stałym na całej swojej długości.
} 
Niedostatek wody jest najważniejszym determinantem australijskiego krajobrazu. Typowy tutejszy widok to równinne połacie spieczonej słońcem ziemi w kolorze cynobru, z rzadka porośniętymi krzakami lub pojedynczymi drzewami. Można powiedzieć, że obraz ten jest powtarzalny, jakby wyszedł spod matrycy lub spod pędzla Andy Warhola.

Jednak oko aborygeńskiego tubylca dostrzega tu znacznie więcej. Gdziekolwiek by się znalazł, zawsze znajdzie miejsce, które czymś się wyróżnia. Może to być wzgórze, wydma, samotna skała, pojedyncze drzewo albo obniżenie terenu czy też zapadlisko (waterhole), na dnie którego można znaleźć wodę nawet w porze suchej. Uważny aborygeński obserwator potrafi je wyodrębnić i zapamiętać, a także - $\mathrm{w}$ razie potrzeby - odnaleźć. Znajomość krajobrazu w tym wypadku decydowała o biologicznym przetrwaniu. Działo się tak przez całe dziesiątki tysięcy lat egzystencji kolejnych pokoleń rodowitych mieszkańców Australii. Dlatego też każde wyróżniające się miejsce ${ }^{9}$ ma swoją nazwę w jednym z języków rodzimych mieszkańców. Sprawia to, że tradycyjna toponimia Australii nie jest uboższa od toponimii np. Europy, mimo że Australia jest od naszego kontynentu o wiele słabiej zaludniona.

Kontynent australijski od niepamiętnych czasów był obszarem, na którym tradycyjne formy ludzkiej egzystencji mogły występować tylko w formie ekstensywnej. Niewielka obfitość naturalnych zasobów sprawiała, że ziemia Australii mogła wyżywić tylko nieznaczną liczbę ludzi operujących na rozległym obszarze. Około 1788 roku, czyli w momencie kontaktu z cywilizacją białych, myśliwsko-zbierackie społeczności znajdowały się w stanie ekonomicznej równowagi z przyrodą. Jeśli nie liczyć konieczności sezonowych wędrówek, ich egzystencja była stabilna przez tysiąclecia. Niepodlegające większym zmianom życie nomadów sawanny dostosowane było perfekcyjnie do ubogich możliwości utrzymania, jakie oferowała im przyroda. Liczebność podstawowej grupy (przeciętna horda zbieraczy i myśliwych liczyła przeważnie kilkadziesiąt osób) oraz wielkość zajmowanego przez nią terytorium były więc ściśle uzależnione od lokalnych warunków naturalnych.

Aborygeni uważali się za istoty należące do przyrody, za jej część, nie zaś za jej właścicieli. Według nich ziemia sprzyja tym, którzy czują się za nią odpowiedzialni, zatem należy żyć z nią w przyjaźni.

Kilka tysięcy lat temu na teren Australii przeniknęły elementy kultury rolnej z obszaru Nowej Gwinei przez Cieśninę Torresa. Wpływy te pozostawiły wiele śladów w kulturze materialnej plemion żyjących w rejonie przylądka Jork. Nie spowodowały jednak gruntownego przekształcenia sposobu życia tamtejszych mieszkańców, tym bardziej nie wpłynęły też na egzystencję plemion sąsiednich. Aborygeni, mając możliwość poznania przynajmniej niektórych technologii rolnych i przyswojenia ich do lokalnych warunków, nie skorzystali z tej okazji. Wydaje się, że zaważył tu sposób podejścia do relacji człowieka z naturą. Dla rodowitych Australijczyków ziemia - rozumiana zarówno jako grunt, jak

\footnotetext{
${ }^{9}$ Por. ich słowiańskie odpowiedniki: uroczysko w języku polskim oraz swiatiliszcze w rosyjskim.
} 
i szerszy obszar ekumeny - jest święta i nie powinno się jej ranić ostrzem żadnego narzędzia. Niezależnie od tego, czy mieszkali w nadmorskich mangrowych zaroślach, na nawodnionym stepie, czy na suchej półpustyni, zawsze byli zdania, że otaczający ich krajobraz należy pozostawić w spokoju. Musi on pozostać niezmienny, ponieważ jest pomnikiem wieczności. $Z$ tej perspektywy techniki rolne, importowane na kontynent z Nowej Gwinei, jawiły się im jako inwazyjne, dlatego odnosili się do nich $\mathrm{z}$ dezaprobatą.

Małą ojczyznę Aborygena stanowił kraj o rozległości od kilkudziesięciu do stu kilkudziesięciu kilometrów. W przypadku grup podejmujących dłuższe wędrówki dystans ten mógł zwiększyć się do dwustu lub nawet więcej kilometrów, wszelako w ścisłym sensie tego słowa ekosystem pojedynczej hordy nomadycznej obejmował obszar możliwy do przejścia przez człowieka w ciągu nie więcej niż dwóch-trzech dni. Gospodarzem takiego terytorium nie był zbiór jednostek, lecz horda jako całość - tradycyjna grupa nomadyczna Australii. Oprócz zbiorowego poczucia odpowiedzialności (odpowiednika europejskiego prawa własności) relacja ta obejmowała również dogłębną wiedzę terenową. Obejmowała ona informacje o rzeźbie terenu, biegu wód, o linii wybrzeża, skałach, wydmach, o rodzajach miejscowej wegetacji, o lokalnym klimacie i pogodzie. „Właściciel” takiego terenu musiał umieć rozpoznawać ślady ludzi, ptaków, zwierząt i owadów, musiał też rozpoznawać potencjalne niebezpieczeństwa, takie jak kumulacja przypływów, zdradliwe prądy czy ukryte przed ludzkim okiem, wypełnione wodą jaskinie ukryte w skałach. Wiedzy tej jednostka nie wykorzystywała na prywatny użytek, lecz dzieliła się nią z całą wspólnotą.

Przeciętna powierzchnia takiego terytorium wzrastała proporcjonalnie do spadku poziomu nawodnienia. W nadbrzeżnych rejonach Ziemi Arnhema, najbardziej wysuniętego na północ skrawka Australii, gdzie do dziś przetrwało 126 grup aborygeńskich, przeciętna wielkość zajmowanego przez tamtejszą wspólnotę terytorium wynosi $235 \mathrm{~km}^{2}$. W miejscach suchych - gdzie, przypomnijmy, przed 1788 roku mieszkała większość plemion rodzimych - obejmowała gdzieniegdzie 10 tys. $\mathrm{km}^{2}$ lub nawet więcej. Tak duże różnice nie wynikały z rozmaitej liczebności grup, lecz ze zróżnicowanych możliwości zaopatrzeniowych ekosystemu: o ile w rejonach dostatecznie nawodnionych do przeżycia jednostki potrzeba było 2,5 $\mathrm{km}^{2}$, o tyle na obszarach suchych wskaźnik ten wzrastał ponad dziesięciokrotnie.

Zarysy tego terytorium najczęściej pokrywały się z zasięgiem miejscowego akwenu: z kształtem zlewiska potoku, rzeczki lub zbiornika wodnego. Na pograniczu dwóch terytoriów wspólnotowych lokowały się widoczne z daleka wzniesienia terenu. Ostańcowe skały czy większe głazy były w praktyce miejscami wspólnymi dla obu sąsiadujących ze sobą hord. Podobnie jak w innych kulturach świata, były to też miejsca sakralne: manifestował tam swą obecność totemiczny przodek jednej z tych grup, lub - jak bywało - nawet obydwu.

Kształt i rozległość miejsc nawodnionych, bieg akwenów - były to podstawowe czynniki wpływające na lokalną aborygeńską kulturę. Australijscy antropolodzy, opierając się na podziale kontynentu na zlewiska, wyróżnili nawet podstawowe strefy tradycyjnej kultury. 
W mentalności rdzennych mieszkańców Australii granicę terytorium podtrzymywał, utrwalał i strzegł jedynie rytuał. Aborygeni nigdy nie stawiali ogrodzeń, gdyż czynność ta była sprzeczna z ich rozumieniem świata zamieszkałego przez człowieka. Siatki i płoty, które pojawiły się tutaj po przybyciu Europejczyków, traktowali jako naruszenie porządku, utrzymującego $\mathrm{w}$ równowadze niebo i ziemię.

Zupełnie inne było też rozumienie przestrzeni i terytorialności. Podczas gdy biali spoglądali na zdobywany obszar jako na powierzchnię, w oczach Aborygenów ich kraina była siecią - splotem pieszych dróg. Miejscowa tradycja zachowała opowieści o wędrujących przodkach, którzy śpiewając, nadawali nazwy kolejnym mijanym miejscom. Zmieniali też język pieśni, przekraczając kolejne terytoria plemienne. Ułożone przez nich „pieśni ścieżek śpiewu” są w oczach współczesnych Aborygenów istotnym elementem spuścizny pozostawionej przez przodków.

Pieśń, będąc swoistym paszportem wędrowca, wyznacza też granice jego wędrówki. Rodzimi Australijczycy czasów prekolonialnych żywili niechęć do wypraw na nieznane terytoria. Poza zatoczonym pieśnią kręgiem znajdowały się - jak wierzyli - obszary nienależące do ich świata, kraina chaosu, której nie objęło błogosławieństwo kreacji. Tylko wewnątrz własnego, ograniczonego ramami opowieści-pieśni świata krajobraz ma określony kształt, a żyjące tutaj istoty dysponują konkretnymi formami egzystencji. Konkretny przykład: aborygeńska mentalność dzieli krajobraz na obszary męskie i żeńskie. W świecie zewnętrznym ta dychotomia już nie działa, podobnie jak nie występuje tam podział na rodzaje i gatunki.

Polski badacz zauważył że „sposób, w jaki Aborygeni odbierają pejzaż, można porównać do oglądania gwiazdozbiorów podczas bezchmurnej nocy. Kosmos jest odbiciem mikrokosmosu" (Bednarowicz 2004). Tę metaforę, całkowicie zgodną ze sposobem myślenia tubylców Australii, można dalej rozwijać:

Kutjungka, podobnie jak ich sąsiedzi Warlpiri, porównują formy krajobrazu do ludzkiego ciała. Drzewa o kopułowatym listowiu nazywane są u nich ngarpalu, które to słowo jest jednocześnie synonimem piersi. Słowo muurpu używane jest na równi do opisania górskiego grzbietu, jak i ludzkich pleców. Jaskinia (pirnki) związana jest etymologicznie z kobiecym łonem, a wypukły spód chmury nazywany jest tjurni, słowem, które $\mathrm{w}$ odniesieniu do ludzkiego ciała oznacza łono lub żołądek (Watson 1999).

Przykład Kutjungka i Warlpiri, plemion żyjących na pustynnych obszarach Wielkiego Płaskowyżu Zachodniego, jest typowy dla wszystkich ludów Australii. Aborygeni odczuwają ziemię, krajobraz - jako czujące i żyjące ludzkie ciało. Ich sposobu myślenia nie można jednak nazwać antropomorfizacją. W tym wypadku jest raczej odwrotnie: to człowiek utożsamia się z krajobrazem, w którym żyje od pokoleń. Rodowici mieszkańcy Australii często mówią o sobie: „Jestem krainą”. To kapitalne określenie pozwala nam uchylić rąbka zrozumienia aborygeńskiego poczucia przestrzeni, a także aborygeńskiej estetyki. Obserwator przyrody nie czuje się w tym wypadku jej częścią, on ,jest" całością swojej krainy. 
Również aborygeńska mitologia jest nierozerwalnie związana z kontekstem miejsca. Mit odnosi się tutaj do krainy, w której jest opowiadany. Plemienna historia opowiedziana poza granicami plemienia przestaje mieć znaczenie dla przedstawicieli wspólnoty, czującej się całością ożywionych i nieożywionych form istnienia, jakie tylko występują w zasięgu ich wzroku.

Nie znaczy to, żeby Aborygenom obce było pojęcie przestrzeni nadprzyrodzonej. Nie lokują jej tylko "gdzieś daleko", lecz umiejscawiają w znanym sobie świecie jako, rzec by można, dodatkowy, równoległy wymiar. W takim rozumieniu przestrzeń nadprzyrodzona nie jest obiektem „z tamtej strony”, lecz raczej tą samą przestrzenią, lecz przemienioną w swojej istocie. Moment zmiany wyrażany jest nie w kategoriach przestrzennych, lecz czasowych. Kluczową rolę odgrywa tutaj pojęcie Snu (altjira w języku aranda), a także blisko z nim związane wyobrażenia Czasu Snu albo Śnienia (altjireringa, ang. dreamtime). Pierwotni Aborygeni nie znali pojęcia snu jako procesu fizjologicznego; $\mathrm{w}$ ich przekonaniu człowiek śniący przechodził do innej rzeczywistości, pozazmysłowej i pozawerbalnej.

Altjira jest rozumiana jako czas przeszły - tubylcy, opisując historię Czasu Snu, używają zwrotu „dawno, dawno temu” - ale ta przeszłość bynajmniej nie jest przez nich rozumiana jako rzeczywistość miniona. Jest to rzeczywistość ponadczasowa, aktywnie obecna w teraźniejszości, a także w przyszłości. Czas Snu jest raczej bezczasem, bez początku ani końca. Sięga w rzeczywistość, w której byty istniały (istnieją? będą istniały?) bez przyrodzonej sobie formy. Nie jest jednak ani marzeniem, ani też stanem umysłu. Altjira, choć obecna "osobno" we wnętrzu każdego człowieka, jest wobec niego rzeczywistością obiektywną i transcendentną. W obszar tej rzeczywistości można wejść przez wizje, tańce, trans i sny. Siła magii występuje niezależnie od posługującego się nią specjalisty, mając swoje źródła w Czasie Przodków.

Możliwość tych kontaktów powoduje, że Czas Snu może być nieustannie aktualizowany w ludzkim działaniu, gdyż w rozumieniu Aborygena sen, podobnie jak transowe wizje, też jest rodzajem aktywności. Domeną tej aktywności jest teraźniejszość (nie: czas teraźniejszy!), traktowana integralnie jako rzeczywistość oddzielona zarówno od przeszłości, jak i przyszłości.

Altjira jest rzeczywistością duchową, nie zaś intelektualną. Przy formułowaniu jakichkolwiek kategorii opisowych czy definicyjnych, większa część rodzimych społeczności Australii odwołuje się do narracji intuicyjnej sugerującej istnienie wymiaru bytu pozostającego poza ludzką wyobraźnią. Fakt, że w kategoriach poznawczych tamtejszych ludów taki wymiar w ogóle istnieje, umieszcza Aborygenów - których tradycyjna kultura materialna zatrzymała się na etapie epoki kamiennej - w rzędzie ludów o wysoko rozwiniętej kulturze duchowej. Przyznają to znawcy tematu na czele z Claude'em Lévi-Straussem, który nazwał Aborygenów „,arystokratami umysłu wśród społeczeństw pierwotnych"10.

\footnotetext{
${ }^{10}$ Wysoką ocenę kultury duchowej Aborygenów, zawartą w eseju Rasa i historia (1952), francuski antropolog powtórzył i rozwinął w pracy Myśl nieoswojona (1962).
} 
Dla zanurzonego w tradycji Aborygena cała ziemia, która go otacza, jest sanktuarium - ale pewne miejsca posiadają jakby status specjalny. Jeżeli znany mu krajobraz jest epifanią rzeczywistości niewyobrażonej, pewne jego elementy traktuje on jako szczególnego rodzaju „kanały transmisyjne” wcielenia. To miejsca, gdzie przodkowie wynurzają się z innego świata, pojawiając się z głębi ziemi lub z wody. Mogą to być też kamienie, skały, jeziorka, szczelina lub zapadliska. $\mathrm{W}$ takich też miejscach mityczne istoty powracają do czasu wiecznego.

Podstawowym źródłem mitologicznej ekspresji jest tutaj obraz, nie zaś rozumiane literalnie słowo, przez które europejski słuchacz dopiero dochodzi do pojęcia obrazu. Aborygeni do dziś w mowie potocznej używają obrazowych odniesień i porównań, „mówią obrazami”. Stąd bierze się nieco surrealistyczny charakter ich opowieści, pozornie nacechowany brakiem logiki i spójności. Obrazy, podobnie jak całe sny, w których owe obrazy zostały ludziom przekazane, są kolorowe. Cała mitologia Australii przesycona jest kolorami oraz ich symboliką.

Kolory są symbolami podstawowych żywiołów. Czerwień to ogień, który w aborygeńskiej kulturze uważany jest za własność duchów. Dlatego człowiek, aby go zdobyć, musiał posunąć się do kradzieży. W mitach często dokonuje jej kobieta utożsamiana ze słońcem. W wierzeniach Aborygenów ogień ma moc uzdrawiającą. Czerwień kojarzona jest też z krwią, a przez krew - z mocą życia. Kolor ten ma więc szczególną moc świętości: oznacza się nim tajemne symbole na tradycyjnych malowidłach. Czerwona glinka jest cenionym elementem tradycyjnych rytuałów.

Z kolei czerń symbolizuje ziemię. Aborygeni symboliczne obszary czerni umieszczają także na niebie, którego ciemne miejsca tłumaczą jako ślady palenisk, pozostawione przez przodków. Żółć symbolizuje wodę. Żółta ochra przypomina plamy na grzbiecie węża, stworzenia, które wśród rodzimych ludów Australii nieodmiennie kojarzone jest z wodą. Wreszcie czwarty kolor, biel, oznacza powietrze i cały rozległy świat niebios wraz ze słońcem, księżycem oraz gwiazdami. Biel to także mistyczny kolor kwarcu - barwa wyobrażeń, w których formułowane są przeżycia szamańskiego transu. Biel jest też atrybutem Istoty Najwyższej, boskiego bytu, który stworzył wszechświat oraz go ogarnia.

Kolory, podobnie jak żywioły, dzielą się na kobiece i męskie. Do tych pierwszych zalicza się czarna ziemia i żółta woda, do drugich - czerwień ognia i biel powietrza. Godzi się jednak zauważyć, że w mitach męscy praprzodkowie rodowitych Australijczyków przybyli na ten świat właśnie „z ziemi i z wody”. Tajemne rytuały przejścia przez ogień i oczyszczenia przez dym, dokonywane przez inicjowanych mężczyzn wewnątrz kamiennych kręgów boro, mają służyć odnowieniu i afirmacji pierwiastka męskości. Rytuał ten przypomina, że kiedyś ogień był domeną kobiet, mężczyznom zaś dostał się ten żywioł dopiero w wyniku zuchwałej kradzieży, której - według mitu - dokonał kruk. Niewątpliwie znajdujemy tu echa jakiejś prehistorycznej ustrojowej przemiany, w wyniku której kobiety utraciły status strażniczek kultu.

Kolor żółty przypisywany jest także warkotce (tjuringa), podstawowemu instrumentowi sakralnemu społeczności aborygeńskich. Tjuringa jest znakiem 
przymierza Istoty Najwyższej ze światem ludzi. Była to największa świętość każdej wspólnoty nomadycznej, przechowywano ją jak relikwię, a dostęp do niej mieli tylko szamani. Wizerunki warkotki do dziś umieszcza się w dziuplach drzew rosnących w pobliżu źródła lub innego zbiornika wodnego.

Aborygeńskiej kulturze znane jest pojęcie symbolu jako rzeczywistości ukrytej. Nie odczuwają jednak potrzeby wyjaśniania tej rzeczywistości metodą dyskursywną, jak czynimy to my, ludzie cywilizacji europejskiej. Zamiast opowiadać osobie przybyłej z zewnątrz o przebiegu inicjacji, pokazują jej kreski na brzuchu inicjowanego - i jest to dla nich zupełnie wystarczające wyjaśnienie. Znamienny był też stosunek tubylców do występujących w pobliżu ich koczowisk rysunków naskalnych lub kamiennych kręgów, których pochodzenia nie znali. Choć nie potrafili wytłumaczyć, kto jest ich twórcą, zawsze „wiedzieli”, co przedstawiają. Źródłem owej „wiedzy” były sny: Aborygeni celowo spali w pobliżu wizerunków, aby przez sen objawiły im się znaczenia tych obrazów.

Malowidła naskalne, występujące na obszarze całego kontynentu, tworzono już 20 tys. lat temu. Ostatnie malunki, wykonane tradycyjnymi technikami przez znających odpowiednie rytuały mistrzów, powstały jeszcze całkiem niedawno, w 1985 roku. We współczesnej sztuce aborygeńskiej stare wzory przeniesiono $\mathrm{z}$ kamienia na malowidła na korze.

W Australii znane są trzy sposoby wykonywania rytów naskalnych: technika punktowania (najbardziej rozpowszechniona), technika rytowania konturów oraz technika puncowania, żywa do dziś w centralnych, pustynnych obszarach kontynentu (zob. Mountford 1989: 266 i nn.). Punktowanie polega na naciskaniu podłoża ostrzem krzemienia. Rytowanie stosowane jest przy ozdabianiu miotaczy oszczepów, tarcz oraz mniejszych przedmiotów, zarówno codziennego użytku, jak i służących do czynności rytualnych. Jako rylec służył tutaj najczęściej ząb oposa, umiejscowiony na rękojeści, bądź to w sposób naturalny (szczęka), bądź za pomocą przymocowania rylca do kija. We wschodniej Australii wycinano kontury znaków kultowych w pniach drzew, używając do tego kamiennej siekiery. Charles Mountford przypuszcza, że pierwotni Australijczycy używali do rytowania ostrych brzegów muszel morskich. Na południowym wybrzeżu, przy obróbce skórzanych okryć, wycinano też - ostrą krawędzią kamienia lub muszli - misterne wzory. Pokrywały one wewnętrzną stronę ubrania. Jeśli chodzi o puncowanie, technika ta przetrwała do połowy XX wieku na terenie środkowej Australii (Mounford 1989: 276). Na tych pozbawionych wody obszarach skały pokryte są najczęściej cienkim brązowym nalotem, który po odłupaniu ukazuje głębszą warstwę, „miąższ” o wyraziście białym kolorze. Odsłaniało się te miejsca przy użyciu ostrza kamiennego narzędzia.

Malowidła jaskiniowe można napotkać w płytkich pieczarach lub w ukrytych pod skalnymi nawisami zagłębieniach. Można z tego wnioskować, że ich twórcy malowali je w miejscach niezbyt oddalonych od światła dziennego - a co za tym idzie, tworzyli bez pomocy ognia (łuczywo, ognisko itd.). Twórcy i użytkownicy tych wizerunków byli przekonani, że odnawianie tych malowideł o odpowiedniej 
porze roku wpływa na rytm przyrody. Przekonanie to przetrwało do dzisiaj w rejonach o dużym natężeniu ludności rodzimej.

Szeroko rozpowszechniony jest motyw odcisku dłoni o rozstawionych palcach. Powstaje on w jak najbardziej prosty sposób. Twórca przeżuwa biały barwnik, który po napełnieniu ust wodą przekształca się w roztwór koloru wapiennego. Gdy „farba” jest już gotowa, człowiek przykłada do kamiennej ściany rozwartą dłon - czasem jest to stopa - i z całej siły pryska na ścianę wapienną wodą z ust. Gdy roztwór zaschnie na tyle, że nie ścieka już po kamieniu, człowiek odejmuje dłoń - pozostawiając jej ślad w postaci niezamalowanego miejsca.

Tego rodzaju ekspresja, wbrew pozorom, ma bardzo długi żywot. Tubylcy bowiem regularnie, mniej więcej po upływie jednego do trzech pokoleń, „odnawiają" negatywy dłoni, czyniąc to taką samą techniką. W ten sposób na kontur dłoni poprzednika nakładany jest negatyw dłoni następcy. Ta kontynuacja, niezwykle sugestywna pod względem siły wyrazu jej symboliki, może trwać od niepoliczonej ilości pokoleń. W aborygeńskiej tradycji malunków naskalnych nie poddawano konserwacji - podmalowywano je jednak, często zmieniając szczegóły lub wygląd przedstawianej postaci. Było to już faktycznie dzieło nowe, choć namalowane "na gruncie” starego wzoru.

Na większości plemiennych obszarów pojawiają się wzory geometryczne w postaci kól, spiral lub powiązanych ze sobą linii, prostych lub elipsoidalnych. Te wyobrażenia, które europejskiemu oku kojarzą się z abstrakcją, są jednak na ogół precyzyjnymi przedstawieniami mitycznych historii. Aborygeński twórca lub też interpretator lokalnego rysunku bez trudu "rozwiązuje” kod tej pozornej łamigłówki, opowiadając o każdym jej szczególe, który przeważnie jest konkretnym epizodem tradycyjnej opowieści. Tak jak szczegóły wizerunku składają się na cały obraz, epizody jego interpretacji składają się na całość mitu. Oczywiście $\mathrm{w}$ wielu wypadkach aborygeński interpretator nie mówi wszystkiego, gdyż nie może zdradzić sakralnych tajemnic, zakodowanych w znakach umieszczonych na skalnej ścianie.

Wizerunki wondżinów to duże postacie duchów, których głowy otacza półokrąg przypominający aureolę. Charakterystyczną cechą wyobrażenia wondżina jest brak ust. Występują na północy, na półwyspie Kimberley. Miejscowi wierzą, że wizerunki te przepełnione są mocą wody i krwi. Wierzeniom tym odpowiada kolorystyka przedstawień: żywioł wody symbolizuje tutaj biel twarzy, natomiast czerwona aureola oznacza krew dającą siłę istotom żywym.

Oryginalną i niepowtarzalną manierę prehistorycznej Australii stanowił tzw. styl rentgenowski. Jego przykłady odnajdujemy we wschodniej części Ziemi Arnhema. Fenomen tego stylu polegał na tym, że twórca, przedstawiając wizerunki ludzi i zwierząt, oddawał nie tylko wygląd zewnętrzny, dostępny zwyczajnemu obserwatorowi, ale uwieczniał też narządy wewnętrzne (stąd nazwa stylu). Malowidła, dochodzące do 2,5 metra długości, składają się z setek cienkich, równoległych linii, malowanych w kilku kolorach.

Przedstawienia z Australii Środkowej mają charakter ilustracyjny: pokazują sceny z codziennego życia lub te spośród mitycznych historii, które nie mają 
charakteru ekskluzywnego, przeznaczonego wyłącznie dla wtajemniczonych. Natomiast puncowane wizerunki z zachodniej części kontynentu przedstawiają treści bardziej skomplikowane ${ }^{11}$. W dorzeczu Murray przetrwały jeszcze inne rodzaje obrazów: wizerunki wydrapywane. Tworzono je przez przeciąganie po powierzchni miękkiej skały kawałkiem twardego drewna.

Bora to sakralne place związane z rytem wtajemniczenia. We wschodniej Australii uczestnicy tych uroczystości żłobili w ziemi rowki, które miały głębokość kilku centymetrów, taką też szerokość. Tworzyły one zespół linii, równoległych, przecinających się, nierzadko skłębionych, które przedstawiały zarówno formy abstrakcyjne, jak i naturalistyczne (kangury, emu, węże albo ludzie). Pokrywały one całą powierzchnię placu ceremonii, nierzadko o powierzchni około $100 \mathrm{~m}^{2}$.

Oryginalnym wykwitem australijskiej kultury materialnej są też malowidła na korze. Aborygeni do niedawna używali płatów kory do okładania szałasów wznoszonych podczas pory deszczowej. Wnętrza szałasów zdobią malunkami i rysunkami. Owe wizerunki bywały często bardzo efektowne, zarówno pod względem formy, jak i kolorystyki. Niestety z uwagi na nietrwałość materiału większość z nich szybko przepadała. Wyruszając do letniego obozowiska w porze suchej, tubylcy nie przenosili ze sobą szałasów, które niszczały. Najwięcej malowideł na korze zachowało się na północy: w Ziemi Arnhema i okolicach.

Wizerunki te, jak powiedzieliśmy, mają z zasady charakter dekoracyjny, powstawały więc w zasięgu wzroku kobiet i dzieci. Tworzono jednak ilustracje tajemnych mitów, w które wprowadzani byli młodzi chłopcy. W takich wypadkach wizerunki na korze niszczono bezpośrednio po ich wykorzystaniu, aby nie zobaczyły ich niepowołane osoby.

Z kory tworzono także tarcze bojowe, owalne, ze szczytami. Gładką powierzchnię kory nacina się w odpowiedni sposób, aby potem wypełnić wycięte rowki białą farbą. Tarcze takie zdobiono motywami geometrycznymi, czasem też rysując postacie ludzkie albo zwierzęce.

Na północnym-zachodzie Australii (półwysep Dampier) podobne wzory wyrzynano na powierzchniach muszli perłowych. Były one zasadniczo przeznaczone dla inicjowanych chłopców, jednak po zakończeniu ceremonii stawały się one przedmiotem wymiany pomiędzy grupami, a także odleglejszymi plemionami. Jak dowiedli badacze, zasięg tej wymiany sięgał dystansu 3 tys. km.

Gdy porównamy dzieła naskalne Aborygenów z twórczością ich kulturowych „rówieśników”, europejskich twórców doby wczesnego paleolitu, naszą uwagę zwróci niższy poziom techniczny wytwórców australijskich. Aborygeni nie stosowali technik właściwych artystom z Lascaux czy Altamiry - nie ma u nich chociażby perspektywy rzędowej. Odpowiedź na pytanie, co o tym zadecydowało: prostota techniki czy też poczucie hieratyczności, którym kierowali się australijscy wykonawcy, pozostaje kwestią dyskusyjną. Znajomość sposobu myślenia ich następców sugerowałaby drugą z odpowiedzi.

\footnotetext{
${ }^{11}$ Mountford uważa, że powstały one stosunkowo niedawno.
} 
Archaizm stosunków społecznych Aborygenów może być też wskazówką przy próbach oceny artystycznych wytworów człowieka pierwotnego - w skali całego globu. Wspólnotowy charakter aborygeńskiej wytwórczości dotyczy bowiem również obszaru, który zwykliśmy określać mianem sztuki.

W wielu częściach Australii sztuka jest własnością grupy i prawa do takich przedmiotów jak obrazy są ściśle chronione i zastrzeżone. Nie znaczy to jednak, aby aborygeńska sztuka pozostawała przez całą swoją historię czymś statycznym. W rzeczy samej jest ona nacechowana różnorodnością regionalnych form, związanych z konkretnymi miejscami. Ale też, wbrew regionalnym zróżnicowaniom, [rodowici - przypis W.B.] mieszkańcy Australii, wzdłuż i wszerz jej obszaru, są wzajemnie połączeni całą siecią powiązań. Sztuka gra znaczącą rolę w tworzeniu kształtu relacji pomiędzy poszczególnymi grupami oraz w wyrażaniu ich tożsamości (Morphy 1998: 6).

Autor tych słów, badacz aborygeńskiej estetyki Howard Morphy, przez odwołanie do kategorii dziedziczenia i odpowiedzialności wyjaśnia istotę motywów aktywności twórczej Aborygenów: „Dzieła sztuki - malunki, rzeźby, pieśni i tańce upamiętniające czyny mitycznych przodków, zostały odziedziczone przez grupy ludzi, które od nich je przejęły" (Morphy 1998: 5).

Artyści malujący wizerunki nie tworzyli wewnątrz swojej hordy osobnej grupy. Malarzem mógł być każdy dorosły mężczyzna. W praktyce zostawał nim osobnik w sposób widoczny bardziej od innych utalentowany plastycznie. Na tym "etacie" artysty hordy mężczyzna ten musiał „rzeźbić proste figurki w drewnie, modelować $\mathrm{w}$ kamieniu lub $\mathrm{w}$ drewnie symbole, przedstawiać $\mathrm{w}$ odpowiedniej technice sceny z mitów na kawałkach kory, ścianach skalnych lub na ziemi" (Mountford 1989: 286). Mógł też otrzymać „polecenie wtajemniczania młodych chłopców w mity i legendy plemienne za pomocą rysunków naziemnych lub malowideł jaskiniowych" (Mountford 1989: 286).

Badacz australijskich ludów rodzimych, Mountford, stwierdzając, że „wszyscy tubylcy są z natury artystami", wyznaje, że:

nie spotkał ani jednego tubylca, który nie umiałby malować i nie wykorzystałby tej umiejętności. Oczywiście niektórzy są bardziej zdolni od innych i wkładają w dzieło więcej wysiłku. Kto jednak obserwuje tych ludzi przy pracy i widzi, jak bardzo przejęci są swoim zadaniem, ten nie ma wątpliwości, że ci prości artyści przepełnieni są takimi samymi uczuciami jak twórcy innych kultur (Mountford 1989: 286).

W plemiennej Australii symbole były podstawowym i niemalże jedynym towarem wymiany. Zapewniały one nietykalność wędrowcowi. Ten, prócz pieśni, przynosił bliższym lub dalszym sąsiadom również rzeczy. Obrót obiektami materialnymi stanowił jednak jedynie wzmocnienie i upamiętnienie właściwej „transakcji”, jaką była wymiana pieśni. 
Przedmioty, noszone podczas rytualnej wędrówki, były też swoistymi „rezonatorami” duchowej siły podczas długiego i wyczerpującego marszu. Aborygeni do dziś wierzą, że niesiony podczas walkabout (rytualnych wędrówek po plemiennym terytorium) bumerang „odżywa w wędrującym” - podobnie jak on sam „odżywa w bumerangu”. Noszone przedmioty stanowiły kumulację duchowej mocy drzemiącej w głębi ukrytego w podróżnej sakwie kawałka kryształu albo w konsze muszli. Przedmioty tego rodzaju według aborygeńskich wierzeń umożliwiają wędrowcowi kontakt $\mathrm{z}$ niebem.

Uczestnicy wspólnot nomadycznych Australii nie traktowali sztuki jako osobnej formy istnienia - dla nich „sztuką" było samo życie. Choć wyrażali swoje uczucia i emocje w wyrazistych formach, w postaci rozpoznawalnej dziś na całym świecie estetyki, nie potrafili owej estetyki ocenić, nie mając możliwości porównania własnych wytworów z formami estetycznymi właściwymi innym kulturom. W ten sposób wiele tysięcy lat izolacja Aborygenów przyczyniła się do wytworzenia swoistego, w skali intensywności, związku człowieka z wytworzonym przez niego dziełem.

To integralne, a jednocześnie nieporównywalne z innymi przykładami kultur etnicznych świata przeżywanie piękna istnienia wyrastało z podświadomości „artysty”, który przecież sam nie uważał się za artystę. „Artysta”, a właściwie twórca, nie występował tutaj jako kapłan, szaman czy znachor - stanowisko, które w obrębie aborygeńskiej kultury moglibyśmy określić ogólnie jako „człowiek wyższego stanu". Jako uczestnik grupy wędrownej indywidualny twórca, podobnie jak pozostali męscy współuczestnicy jego wspólnoty, był „tylko" powiernikiem rzeczy stworzonych. Swoim aktem twórczym miał za zadanie podtrzymywać istnienie powierzonych sobie bytów - jako symboli i przedmiotów.

Jak każda sztuka etniczna sztuka aborygeńska pojawiła się w postaci fenomenu rodzącego się w pojęciowym trójkącie: człowiek - świat - dzieło. Miała ona wszakże inne zadania niż definiowana w podręcznikach sztuka „klasyczna”. Sztuka, jaką znamy w Europie, pragnie przez dzieło upamiętnić człowieka, przekraczając ograniczenia jego śmiertelności. Dzieło - w rozumieniu europejskiego artysty - winno przeżyć swojego twórcę, uwieczniając go w pamięci potomnych. Tymczasem tradycyjne wytwory aborygeńskich artystów bywały na ogół nietrwałe. Tworzone przeważnie na piasku lub na skórze ludzkiego ciała skazane były na szybkie zatarcie. To, że pewne malunki naskalne przetrwały przez wiele pokoleń, było na ogół zasługą kolejnych mistrzów, którzy na istniejące już formy nakładali nowe warstwy ochry. Nie była to jednak - jak już powiedzieliśmy - konserwacja, ale kontynuacja.

Według Mountforda wytwory aborygeńskiej kultury materialnej przenika rys „sztuki świeckiej”:

twórca ma swobodę i może wybrać każdy motyw i każdą formę, jaka przyjdzie mu do głowy lub mu się podoba. Nieskrępowany konwencją artysta nie tylko stara się wiernie oddać życie plemienne, lecz nie cofa się również przed przejmowaniem nowych idei i form od sąsiednich plemion czy nawet od „obcych intruzów" (Mountford 1989: 289). 
Zgłębianie przez Europejczyka istoty sztuki Aborygenów wymaga od badacza postawy odejścia od utrwalonych pojęć filozoficznych i estetycznych. Nie mają tutaj zastosowania akademickie podziały na sztukę sakralną i świecką, sztuki piękne i sztukę użytkową.

Przykłady można mnożyć dalej. Tradycyjny model aborygeńskiej „ekspresji artystycznej" wydaje się nam, Europejczykom, modelem w niewielkim tylko stopniu nakierowanym na transcendencję (rozumianą jako dążenie do przekraczania samego siebie). Większość spośród dzieł tworzonych przez Aborygenów nie ma charakteru rytualnego. Rzeźbione słupy pogrzebowe, nawet naskalne malunki czy tajemnicze wzory kreślone na piasku w ścisłym sensie tego słowa nie służyły „przekraczaniu” poznawalnej zmysłami rzeczywistości. Sensem ich wytworzenia oraz istnienia była afirmacja świata doczesnego, podtrzymywanie go w wielości stworzonych gatunków.

Z drugiej strony trudno jest taki rodzaj wytwórczości określać mianem sztuki klasycznie immanentnej. Pamiętajmy bowiem, że relacja twórcy do rzeczywistości odnosi się tutaj w równej mierze do Krainy Snu, obszaru, który nie jest tożsamy z ekumeną, światem zaludnionym przez człowieka. Umysłowość Aborygena niweluje radykalny, dychotomiczny podział na "ten" i "tamten": świat, w którym obowiązują prawa fizyki, oraz obszar, w którym dominuje to, co nadprzyrodzone. Wejście w rzeczywistość mitu nie jest przekroczeniem magicznego kręgu, oddzielającego sferę idealną od realnej, lecz potwierdzeniem ładu rzeczywistości istnienia. Aborygeńskie niebo „,jest odbiciem mikrokosmosu" (Bednarowicz 2004: 190), świata, w którym człowiek porusza się na co dzień. Można powiedzieć, że plemienni Aborygeni nie żyli nadzieją przemiany, jaką w wielu religiach obiecuje wizja "tamtej strony" - oni już żyli w przemienionym świecie.

Sztuka aborygeńska, operując jak najbardziej ubogim instrumentarium technicznym, potrafiła nie tylko przybrać niepowtarzalne formy estetyczne, ale też wznieść się na poziom „duchowego arystokratyzmu”, niedostępny wielu ludom znajdującym się na daleko wyższym poziomie materialnego rozwoju:

Inaczej niż w prozie, interpretacja obrazów i wzorów aborygeńskich nie polega na prostych odpowiednikach (przedmiotu do jego znaczenia) ,,jeden do jednego", ale - podobnie jak w poezji, z całą właściwą jej zawiłością, wielością odniesień i zamierzoną dwuznacznością - każdy symbol albo wizerunek w obrębie dzieła może być zalążkiem wieloznaczności (Caruana 1993: 14).

\section{Nowa Gwinea}

Jak Australia pośród kontynentów zajmuje miejsce szczególne, tak Nowa Gwinea, traktowana jako subkontynent, jest również wyjątkowa. Izolowana rozległymi połaciami oceanu, pod względem tradycyjnej kultury pozostaje obszarem o strukturze archaicznej i wyjątkowo mało podatnej na zewnętrzne wpływy. Ta hermetyczność ma jednak swoje granice: z zamierzchłych epokach Nowa Gwinea stanowiła pomost, którym kolejne fale populacyjne podążały na podbój 
dalszych partii Oceanii. Relikty owych migracji można prześledzić, analizując kultury etniczne współczesnych ludów, zamieszkujących tę wyspę.

Druga co do wielkości wyspa świata zajmuje powierzchnię 829 tys. km², rozciągając się na ponad 2,5 tys. km wzdłuż osi biegnącej z północnego-zachodu na południowy-wschód. Na zachodnim krańcu owej osi znajduje się półwysep Doberai $^{12}$, z racji swojego kształtu nazwany przez Holendrów Ptasią Głową (Vogelkop), na południowo-wschodnim - półwysep Gór Owena Stanleya, gdzie leży Port Moresby, stolica Papui-Nowej Gwinei (PNG).

„Kręgosłupem” całej wyspy jest łańcuch górski, wulkanicznego pochodzenia, którego najwyższe wypiętrzenia to Puncak Jaya (dawna nazwa: Carstensz, 5030 m n.p.m.) i Puncak Mandala (4700 m n.p.m.) w części indonezyjskiej oraz Mount Wilhelm (4509 m n.p.m.) w Papui-Nowej Gwinei. Łańcuch ten przebiega przez środek wyspy, dzieląc ją na dwie części: północną i południową, mniej więcej równe pod względem powierzchni. O ile ta pierwsza zachowuje górzysto-wyżynny charakter (niektóre wzniesienia osiągają tam wysokość ponad 4000 m n.p.m.), o tyle część południowa jest płaską, miejscami bagienną niziną, która od południa styka się bezpośrednio z głównym pasmem górskim. Tutaj też znajduje się największa z rzek wyspy, Fly, uchodząca do Zatoki Papuańskiej. Zarówno źródła Fly, jak i jej ujście leżą na terytorium PNG, chociaż rzeka w swoim środkowym biegu stanowi granicę między dwoma państwami. Digul, druga co do wielkości rzeka na południu, płynie w indonezyjskiej części wyspy. Obie wspomniane rzeki utworzyły w swoich estuariach pokaźne delty. Rozległą deltę tworzy także nieco mniejsza od nich Kikori, uchodząca do morza na wschód od Fly, na centralnym odcinku Zatoki Papuańskiej. Inaczej z rzekami północy (Sepik w PNG, Mamberamo w części indonezyjskiej), które przebijają się ku oceanowi przez łańcuch przybrzeżnych gór. Wody rzeki Sepik jednak, zanim dopłyną do ujścia, przecinają rozległą, bagnistą równinę, porośniętą lasem tropikalnym.

Lasy wysokogórskie zajmują najwyższe partie Gór Śnieżnych i Grzbietu Środkowego, resztę obszaru górskiego, na wysokości 2000-4000 m n.p.m., porastają górskie odmiany drzew tropikalnych. Lasy mangrowe spotykamy na bagiennych nizinach, w dolnych partiach dużych rzek, gdzieniegdzie też występują większe skupiska lasów monsunowych (okolice wyspy Dolak w Papui indonezyjskiej). Tropikalna roślinność nawadniana jest deszczami, które przynoszą tutaj monsuny wiejące od grudnia do marca.

\footnotetext{
${ }^{12} \mathrm{Na}$ zachodniej, należącej do Indonezji połowie wyspy, oficjalnie obowiązuje indonezyjskie nazewnictwo geograficzne. Nazwy miejscowe w języku indonezyjskim wprowadzono $\mathrm{w}$ ostatnim dwudziestoleciu XX wieku, zastąpiły one nazwy o pochodzeniu przeważnie kolonialnym, nadawane przez Holendrów. Pozostawiono tylko niektóre, np. łańcuch wniesień na północnym-zachodzie wyspy nadal nosi nazwę Gór Van Reesa. Większość nazw miejscowych (za wyjątkiem kilku szczytów powyżej 4000 m n.p.m.) ma też oczywiście swoje odpowiedniki rodzime, jednak z racji wielojęzyczności Nowej Gwinei obiekty te mają z reguły po kilka nazw plemiennych. Obecnie nazewnictwo rodzime zachowała większość rzek oraz mniejsze miejscowości. Nazwy w języku indonezyjskim obecne są szczególnie w zachodniej części wyspy poddanej największemu naciskowi osadniczemu.
} 
Jeśli więc pominąć pasma górskie i wybrzeża, pozostanie nam tropikalna dżungla, która porasta zdecydowaną większość całej reszty wyspy. To podstawowy wyznacznik jej geografii, a w konsekwencji także kultury. Gęste lasy i zarośla zawsze uniemożliwiały jakąkolwiek komunikację lądową. Do dziś sieć drogowa w PNG, a w jeszcze większym stopniu w części indonezyjskiej, rozwinięta jest $\mathrm{w}$ stopniu zaledwie zalążkowym. Podstawę komunikacji i transportu stanowi tam, z konieczności, ruch lotniczy. Na większych rzekach istnieje też transport wodny, wszelako nigdy - również w czasach prekolonialnych - nie osiągnął on znaczących rozmiarów. Kręte rzeki Nowej Gwinei płyną powoli po równym terenie, pełne są też zdradzieckich mielizn, których lokalizacja zmienia się z każdym sezonem deszczowym.

Ani pierwsi mieszkańcy wyspy, ani też ich następcy nigdy nie stosowali forsownej ekspansji na terenach leśnych. Nie znano tutaj na wielką skalę wypalania lasów, ani też karczunku, który np. w Europie stał się podstawą tworzenia większości obszarów uprawnych. Gęsta, żywotna i odradzająca się dżungla skutecznie niwelowała wszelkie $\mathrm{w}$ tym kierunku próby - o ile podejmowano je przy użyciu tradycyjnych technik. Dlatego tradycyjne osadnictwo nigdy nie wykraczało tu poza obręb szeroko rozumianej homeostazy: zachowanie stanu równowagi z naturalnym środowiskiem było zawsze górnym progiem nasycenia terenu stałą populacją. Wioski w lasach tropikalnych rozsiane są na tyle rzadko, że nie zmieniają otaczającego je krajobrazu.

Wypływa stąd kilka konsekwencji. Pierwszą, zasadniczą, jest wzajemna izolacja nowogwinejskich wspólnot etnicznych. Podobnie jak cała wyspa, jest swego rodzaju wyjątkowym izolatem na tle innych regionów świata, zamieszkujące ją poszczególne etnosy (od konfederacji plemiennych, poprzez plemiona, aż po najliczniejsze tu małe, jedno- lub kilkuwioskowe wspólnoty) stanowią rozproszone i różniące się nawzajem „wyspy”. Dotyczy to olbrzymiej większości spośród ponad 800 wspólnot etnicznych (zróżnicowanych według kryterium językowego), które zamieszkują obie części Nowej Gwinei.

Ten stan rzeczy, jak się wydaje, trwa bez większych zmian od epoki pierwszych fal osiedleńczych wyspy. Osadnicy, zająwszy określoną niszę - najczęściej leśną dolinę - pozostawali na miejscu, nie utrzymując bardziej intensywnych kontaktów z sąsiadami. Ci ostatni pozostawali oddzieleni pasem nieprzebytej dżungli. Tym sposobem system osadniczy Nowej Gwinei przypominał, i w dużej mierze nadal przypomina, rozrzuconą konstelację (nie sieć!) ludzkich enklaw, polan zaszytych w głębi tropikalnego lasu. Izolowane wspólnoty ukształtowały z czasem odrębne minikultury posługujące się odmiennymi i niezrozumiałymi przez sąsiednie grupy etnolektami. Położona na leśnej polanie wioska, zabudowana drewnianymi chatami i licząca 100-150 mieszkańców, jest typowa dla kultury wczesnego osadnictwa Papuasów.

Nowogwinejczykom nie wpajano poczucia emocjonalnego związku z otaczającym ich rodzinne sioło krajobrazem. Góry, rozciągające się w zasięgu wzroku z większości papuaskich osad, nie mają swoich mitów ani też często nawet nazw. Papuasi nie wiążą z nimi ani opowieści o swoich prapoczątkach, ani heroicznych 
mitów o bohaterach. Związek z krajobrazem zastępuje im co innego: mit rodowej przynależności. Tradycyjne wspólnoty plemienne Nowej Gwinei to związek od kilku do kilkunastu klanów, wielkich rodzin, których układ skomplikowanych powiązań reguluje ściśle przestrzegane prawo zwyczajowe.

Dzisiaj ponadplemiennym, stosowanym na terenie całej Papui-Nowej Gwinei odpowiednikiem tego określenia jest wantok: ten synonim krewniaka dosłownie znaczy ,jedna mowa”. W kulturze europejskiej byłby to synonim dużej liczebnie i rozległej terytorialnie grupy etnicznej posługującej się odrębnym językiem. Na Nowej Gwinei jest inaczej. Skoro każda spośród bez mała tysiąca jedno- lub kilkuwioskowych wspólnot o charakterze rodowo-plemiennym mówi odrębnym etnolektem - to właśnie ten niezbyt rozległy horyzont, ogranicza obszar tak definiowanej wspólnoty. Wantok to pojedynczy zbiór ludzi połączonych ścisłymi więzami rodowej i plemiennej przynależności. To „krewniacy”, „ziomkowie” $\mathrm{i}$ „,rodacy” w pełni znaczenia wszystkich tych trzech pojęć. Jednostka ludzka na Nowej Gwinei - o ile tylko myśli tradycyjnymi kategoriami - zawsze i w każdej sytuacji będzie się uważać za część owej „jednej krwi” lub też „jednej mowy”. Inaczej jednak niż w obszarze kultury europejskiej owa przynależność nie tylko nie tłamsi i temperuje indywidualnej osobowości, ale wręcz jest niezbędnym warunkiem jej istnienia. Osobowość bowiem, podobnie jak poczucie tożsamości, są na Nowej Gwinei budowane poprzez relacje.

Takie rozumienie wzajemnego stosunku jednostki i wspólnoty jest podstawą sensu obrzędu inicjacji. Ma ona bowiem, przez rytuał przejścia, ustanowić nowego człowieka, a właściwie - dopiero teraz - w pełni tego słowa osobę ludzką, która dzieli przynależną sobie część praw i odpowiedzialności w obrębie rodziny nuklearnej, wielkiej rodziny, klanu, wreszcie plemienia.

Prawo zwyczajowe odnosi się też do pojęcia własności, której poczucie w papuaskich społecznościach rolniczych - inaczej niż u Aborygenów - jest silnie rozwinięte. Każdy członek plemiennej wspólnoty jest od urodzenia identyfikowany jako przedstawiciel jednego z totemicznych rodów. Jest to przynależność obowiązująca przez całe życie, od której nie ma odwołania. Własność, tak jak posiadanie ziemi, jest zawsze czymś względnym. Uważa się, że ziemia wraz z porastającą ją roślinnością, drzewami, krzakami, skałami i potokami, należy w tym samym stopniu do żyjącego pokolenia, jak jego przodków i potomków, a także duchów miejsca. Zachodzi też relacja odwrotna: do danego kawałka powierzchni ziemi, wraz z roślinnością i przyrodą nieożywioną, która dla Papuasów też żyje swoim własnym życiem, należą wszyscy ludzie aktualnie żyjący, zmarli i ci dopiero mający się narodzić, a także masalaje ${ }^{13}$. Czyjąś rzecz można wziąć do ręki, można jej użyć, granicą ingerencji w cudzą własność stanowi ryzyko uszkodzenia jej. Nie wolno też samowolnie pozwalać sobie na takie traktowanie cudzych przedmiotów, które mogłoby wpłynąć na zmianę ich właściwości. Przedmiot należący do innych ludzi, nawet jeśli zostanie użyty do własnych potrzeb, nie może zmienić swoich właściwości.

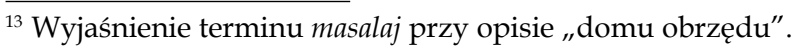


Przywiązanie do „własnego” kawałka ziemi, typowe dla mentalności rolnika, obce jest nomadom, żyjącym w krajobrazie nienaruszonym przez człowieka. Dlatego „leśne” tymczasowe osady, gdzie tradycyjnie dominowały najmniej zaawansowane technicznie formy gospodarki rolnej, przez samych swoich mieszkańców nie były uważane za siedziby „ludów lasu”. Papuasi, choć od niepamiętnych czasów mieszkali w tropikalnej puszczy, zawsze bali się lasu, uważając go za żywioł obcy i nieprzyjazny. Las dla myślącego tradycyjnymi pojęciami Papuasa jest miejscem, w którym mieszkają demony, złośliwe duchy czyhające na ludzi i zwodzące ich ku zatracie w matecznikach i głębokich bagniskach. Lęk przed pozostaniem samemu w nocy w lesie poza macierzystą osadą jest wątkiem determinującym akcję licznych miejscowych opowieści.

Papuasi lękają się też „ludzi lasu”, niskorosłych mieszkańców zielonego interioru, którym melanezyjskie legendy często nadają cechy półdemoniczne. W opowieściach tych - jak się wydaje - zachowała się pamięć o najwcześniejszej fazie ludzkiego osadnictwa. Reprezentowały je wspomniane już wcześniej ludy, które pod względem rasowym odpowiadały typowi negryckiemu. Niscy wzrostem, pigmejowaci Negryci przybyli na teren Nowej Gwinei około 50-60 tys. lat temu, korzystając z ówczesnego niskiego stanu wód oceanicznych. Ci zbieracze i łowcy nie naruszali środowiska i osiedlali się w miejscach o słabszej intensywności wegetacji zieleni, w których - bez konieczności usuwania drzew i krzaków można było sklecić kilka stojących obok siebie szałasów. W ten sposób, w pierwszym rzucie osadniczym, nowogwinejscy Negryci opanowali prawdopodobnie większość obszarów nizinnych. Pamiętajmy wszakże, że chodziło tu o małe grupy, zajmujące duże obszary - gęstość zaludnienia była wówczas bardzo mała. Negryci nie tyle więc „opanowali” wyspę, ile rozproszyli się na jej terytorium, nadając nowogwinejskiem osadnictwu rzeczony już rys izolacji.

Kiedy później, 20-30 tys. lat temu, przybyły na wyspę kolejne fale populacji (odpowiadające murrayańskiej i karpentariańskiej fazie osadnictwa Australii), przybysze zaczęli stopniowo wypierać Negrytów w kierunku gór położonych w środkowej części lądu. Tam też, u podnóża wysokiego łańcucha Gór Śnieżnych (nazwa tradycyjna, obecna indonezyjska nazwa: Pegunungan Maoke), oraz ich wschodniego przedłużenia, Grzbietu Środkowego (Central Range), zachowały się etniczne relikty tej najwcześniejszej fazy osadniczej. Najwięcej cech recesywnych przetrwało u etnosów zamieszkujących indonezyjską Papuę: ludy Citak, Korowai, Kombai i inne, przez sąsiadów określane wspólnym mianem „ludzi lasu”14.

Wspólnoty owe, szczególnie budujące swe domostwa na drzewach Korowai, wyróżniają się niskim wzrostem. Ekologiczną niszą „ludzi lasu” są tereny skrajnie niedostępne, położone w górnych biegach rzek Pulau i Digul, gdzie wilgotny, bagnisty grunt sprzyja intensywnej podzwrotnikowej wegetacji. Są to tereny o wyjątkowo słabym zaludnieniu, a lokalne, małe wspólnoty rozrzucone są na tyle daleko od siebie, że do niedawna niektóre z nich (u Korowai) nawet nie wiedziały

\footnotetext{
${ }^{14}$ Współczesne nazewnictwo indonezyjskie przejęło tę manierę, określając etnosy żyjące na południe od Puncak Mandala jako orang hutan („ludzie lasu”).
} 
o istnieniu sąsiadów o innym pochodzeniu etnicznym. Są to też miejsca, gdzie najpóźniej nastąpił pierwszy kontakt z białym człowiekiem: w wypadku Korowai stało się to w 1974 roku, u Kombai w 1982 roku. Tereny te mają typowo refugialny („ucieczkowy”) charakter: dalej nie można już było ustępować, gdyż od północy zieloną nizinę odgradza wysoka ściana gór.

Kilka miejsc o podobnym, choć bardziej zatartym kolejnymi migracjami charakterze znajduje się także w PNG. Ogólnie etnosy mniej lub bardziej związane z kulturą „ludzi lasu” nie występują już na wyspie w czystym charakterze, nigdzie też nie ma czystej rasy negryckiej. Wymienione relikty etniczne pozwalają jednak na ogólne odtworzenie przebiegu zmian migracyjnych na Nowej Gwinei w ciągu ostatnich kilkudziesięciu tysięcy lat. Negryci, którzy początkowo osiedlali się wzdłuż wybrzeży, z czasem zostali wyparci do podnóży górskich lub w wyżynne doliny w głębi skalistych łańcuchów, w obu wypadkach zamieniając ekosferę typu namorzynowo-leśnego na leśno-tropikalną.

Papuascy przybysze reprezentowali niewiele wyższy pod względem zaawansowania technologii stan kultury materialnej. Podobnie jak Negryci, byli zbieraczami i myśliwymi, być może jednak potrafili już gromadzić i przechowywać ziarna dzikich roślin, które następnie spożywano w miejscu obozowania. Podobnie jak pigmejscy sąsiedzi, mieszkali w szałasach, $\mathrm{z}$ tą jedynie różnicą, że ich szałasy były obszerniejsze, zaś osady nieco ludniejsze. Papuasi, podobnie jak Negryci, żyli w izolowanych grupach, byli stabilni terytorialnie, mimo półnomadycznego charakteru trzymali się tej samej okolicy i z reguły nie podejmowali ekspansji na sąsiednie tereny.

Taki stan rzeczy zmienił się najpóźniej około 9 tys. lat temu, kiedy to Nowa Gwinea, podobnie jak inne miejsca na Ziemi, stała się teatrem mezolitycznej zmiany, której efektem było upowszechnienie rolnictwa. Wiemy to dzięki odkryciu dokonanemu pod koniec XX wieku na bagnach Kuk, leżących w rozległej górskiej dolinie, w centralnej części wyspy (prowincja West Highlands w PNG): rozpoznane tam relikty kanałów irygacyjnych pochodzą z około 7 tys. p.n.e. Jak wskazują wyniki badań, uprawiano tam te same gatunki roślin jadalnych, które również dzisiaj są podstawą pożywienia w wiejskich regionach „wyżynnej” części wyspy.

Nowa Gwinea nie posiada wyżyn, przynajmniej w takim rozumieniu owego terminu, jaki odnosi się do wielkich, pozbawionych drzewostanu, płaskich obszarów wyżynnych Azji i Afryki. Nie rozwinęła się tutaj też kultura wyżyn górskich, typowych dla Andów czy Tybetu, gdzie podstawą egzystencji stała się hodowla. „Wyżyny” Nowej Gwinei to właściwie szerokie górskie doliny, wszelako rozległe na tyle, że dają możliwość bardziej skondensowanego osadnictwa rolnego.

Typowym przykładem może być tutaj dolina rzeki Baliem w indonezyjskiej Papui oraz łańcuch dolin w środkowej partii Wyżyn (Highlands) w PNG. Są to miejsca również relatywnie izolowane z racji trudnych do przebycia, wysokich pasm górskich, okalających je zarówno od północy, jak i od południa (z tego też powodu rozległa i ludna dolina Baliem została odkryta dopiero w 1938 roku podczas rekonesansowego lotu awionetki). Znacznie łatwiejszy pod względem komunikacji 
i transportu szlak łączy je na równoleżnikowej osi zachód - wschód. Wzdłuż tejże osi poruszali się zapewne kolejni migranci. Pierwsi Papuasi zamieszkali tutaj, podążając za Negrytami, już w najwcześniejszej fazie osiedleńczej. Po 50 tys. r. p.n.e., tutaj też powstały pierwsze, stosunkowo duże i stosunkowo gęsto osadzone osiedla.

Tą samą drogą dotarły tutaj wynalazki epoki mezolitycznej i neolitu, kiedy to szybko wzrastająca liczba ludności Ziemi zmusiła część jej mieszkańców do intensyfikacji produkcji zapewniającej środki do przeżycia. Od strony archipelagów indonezyjskich, gdzie rozwinęła się kultura rolna uprawy kokosa i drzewa chlebowego, przetransportowano tutaj techniki, które - adaptowane do miejscowych warunków - stworzyły nowogwinejską odmianę prostego rolnictwa. Jest kwestią do dyskusji, czy techniki te importowano, czy trafiły tutaj one z jakąś kolejną falą osadników. Gdyby prawdziwą okazała się druga hipoteza, nowe ludy przemieszczałyby się tak, jak w średniowieczu migrowała w Europie pasterska ludność wołoska: wzdłuż łańcucha gór (Karpaty). Z tą różnicą, że rolnicy opanowywaliby tu nie górskie stoki (kolonizacja właściwa dla wspólnot pasterskich), lecz doliny.

Tak czy owak „wyżyny” centralnej części wyspy stały się areną rozwoju najwcześniejszych kultur rolnych, współczesnych tym z Bliskiego Wschodu oraz znad wielkich rzek Chin. Uprawy otrzymywano przez wypalanie niewielkich połaci buszu; na wypalonym obszarze kopano dołki, w których składano nasiona uprawianej rośliny. Ten ekstensywny sposób kultywacji wymagał co kilka lat zmiany ziemiopłodu. Z uprawami przenoszono się więc na płaski stok sąsiedniego wzgórza, aby po kolejnych kilku latach powrócić na stare miejsce, gdzie gleba odzyskała swą żyzność.

Z rozwojem rolnictwa związane są dwa wynalazki, które determinowały kształt kultury materialnej ludów Nowej Gwinei przez tysiące lat aż do czasów obecnych. Drewniany kij kopieniaczy, służący do drążenia zagłębień w ziemi, używany jest do dzisiaj w wielu wioskach wyspy, w PNG, a w jeszcze większym stopniu w części indonezyjskiej. Kij kopieniaczy stał się też w wielu lokalnych kulturach symbolem pracowitości. Kamienne żarna do mielenia ziaren, wyjęte żywcem z epoki neolitu, nadal są niezbędnym elementem wyposażenia większości gospodarstw rodzinnych.

Kolejnym kapitalnym elementem miejscowej kultury stała się świnia, udomowiona lub raczej przetransportowana do Nowej Gwinei z zachodu, od strony Indonezji. W lokalnych wspólnotach rolnych zwierzę to stanowi podstawowy miernik zamożności rodziny. W wielu regionach do dzisiaj świnia jest przelicznikiem wszystkich poważniejszych aktów wymiany handlowej jako „waluta", nadal nie dopuszczając do powszechnego obrotu zarówno pieniędzy PNG, jak i indonezyjskich. Niepisane kodeksy etyczne większości plemion głoszą, że w żadnym wypadku nie można ukraść świni, która jest podstawą utrzymania domowego gospodarstwa.

Do ważnych elementów kultur rolnych, wzbogacających aż do dzisiaj życie codzienne Papuasów, są naczynia z gliny, z reguły zdobione kolorowymi farbami, 
a także palafity, czyli domy budowane na palach. Ten ostatni wynalazek wyraźnie wskazuje na miejsce, z którego przybyli eksporterzy rolnych technologii: w stawianych na palach domach także współcześnie żyje znakomita część ludów Indonezji, Malezji oraz Filipin.

Narodziny gospodarki rolnej pozwoliły miejscowym wspólnotom rozrosnąć się liczebnie i okrzepnąć. Powstawały więc duże wioski, które z czasem integrowały się $\mathrm{w}$ procesie wymiany technik rolnych oraz ziemiopłodów. Echem tej integracji jest istnienie do dzisiaj największych nowogwinejskich etnosów mówiących osobnymi etnolektami. Najliczniejszy z nich, lud Enga (od którego pochodzi nazwa jednej z prowincji PNG, co w tamtejszych warunkach jest ewenementem), szacuje się na około ćwierć miliona populacji. Sąsiedzi Enga, lud Huli, zamieszkuje rozległy teren w środkowej części prowincji Southern Highlands, na południe od głównego łańcucha Grzbietu Środkowego. Kolejnym dużym etnosem jest lud Melpa z okolic Mount Hagen (Western Highlands, zachodni sąsiedzi Enga). W indonezyjskiej Papui do tej kategorii wspólnot etnicznych należą Lani (w tradycyjnej literaturze mylnie zwani Zachodnimi Dani), mieszkający na zachód od Doliny Baliem, oraz Ekari, zachodni sąsiedzi Lani, których osady okalają węzeł komunikacyjny Enarotali, miasteczko leżące na północ od grani Pegunungan Maoke.

Wszystkie wymienione wspólnoty - Enga, Huli, Melpa, Lani i Ekari - do których dołączyć należy takie społeczności jak Dani (odkryci w 1938 roku), zamieszkujący Dolinę Baliem, reprezentują do dzisiaj żywą i barwną kulturę etniczną. Ich rodzime języki używane są powszechnie, przynajmniej w miejscach tradycyjnego zamieszkania (co jest kontrastem wobec dużej części etnolektów PNG, które wymierają, będąc zastępowane przez tok pisin, język porozumienia ponadetnicznego), a liczba aktywnych użytkowników lokalnej kultury wzrasta.

Wymiana idei, technik i towarów, za którą być może szła migracja, stworzyła oś komunikacyjną na linii wschód - zachód, równoległą do biegu górskich łańcuchów centralnej części wyspy. Jej powstanie było niejako rewolucyjnym wydarzeniem w pradziejach Nowej Gwinei, gdyż rzeczona oś przełamała tradycyjną izolację tego terytorium. Ludy mieszkające wzdłuż niej, choć nadal rozwijały się osobno, w pewien sposób się upodobniły, także pod względem języka. Współcześni lingwiści wyróżniają więc szeroką, liczącą około 400 etnolektów (połowa języków całej wyspy) rodzinę transnowogwinejską. Jej zasięg w dużej mierze pokrywa się z lokalizacją gór i górskich wyżyn. Pas języków rodziny transnowogwinejskiej, pozostając częścią zbioru języków zwanego językami papuaskimi - genetycznie niejednorodnego, niedostatecznie zbadanego i sklasyfikowanego - na tle „papuaskiej" mozaiki lingwistycznej jest jedynym językowym podzbiorem wyraźnie dającym się wyróżnić pod względem słownictwa i gramatyki.

Podstawę tradycyjnych upraw rolnych stanowi na Nowej Gwinei kilkanaście gatunków jamów (Dioscorea L. albo po polsku pochrzyn), taro oraz kaukau, słodkie ziemniaki. Wymienione produkty od czasów neolitycznych do dziś są na wsi nowogwinejskiej najważniejszymi składnikami codziennego pożywienia. Taro, czyli kolokazja jadalna (Colocasia esculenta), lepiej przyjmuje się na obszarach 
wyżynnych. Australijski lingwista Malcolm Ross z uprawą tej właśnie rośliny wiąże powstanie rodziny języków transnowogwinejskich (Ross 2005). Wraz $\mathrm{z}$ upowszechnieniem uprawy tej rośliny kultura rolna ekspandowała na kolejne obszary śródgórskich dolin, tworząc $\mathrm{w}$ finalnym efekcie równoleżnikowo rozciągniętą strefę etnolektów.

Z kolei jamy pełnią w kulturze nowog winejskiej ważną rolę w obrzędowości, nakierowanej na integrację wspólnoty. Jako takie uważane są za rośliny o szczególnym statusie. Jamy występują $\mathrm{w}$ miejscowych mitach, są też objęte tabu $\mathrm{w}$ wielu plemionach niektóre ich gatunki mogą uprawiać jedynie mężczyźni po inicjacji.

Stopniowe powiększanie zaludnienia, jako konsekwencja ulepszania technik uprawy, doprowadziło jednak do ważnych "skutków ubocznych" w postaci rywalizacji o ziemię. Ekstensywny sposób jej uprawiania wymagał zdobywania kolejnych areałów, co zwłaszcza na mniej urodzajnych terenach górzystych stanowiło problem, który wzrastał z pokolenia na pokolenie. Doprowadziło to do agresji lokalnych wspólnot wobec najbliższych sąsiadów, a w konsekwencji do wojen międzyplemiennych. Wojny te, toczone od niepamiętnych czasów aż do niedawna ${ }^{15}$, stały się specyficzną częścią kultury plemion rolniczych. Zaznaczyć tu należy, że na terenie, gdzie lokalne wspólnoty posługują się etnolektami z rodziny transnowogwinejskiej, w większości przypadków nie stosowano trwałej ekspansji, a poszczególne plemiona pozostały wierne niepisanej zasadzie trzymania się własnej okolicy, a w szczególności swojej niszy ekologicznej. Wojny toczono jednak $\mathrm{w}$ trybie rytualnym, z niemal coroczną regularnością. Przeważnie walczyły ze sobą dwa sąsiednie plemiona, rzadkością były wojenne koalicje, jak również dalsze wypady militarne.

Niektóre ze wspólnot prowadziły jednak, i to w sposób permanentny, wyprawy zbrojne, sięgające nawet kilkuset kilometrów. Należał do nich lud Marind, zamieszkujący zalesione niziny w górnych biegach rzek Biau, Kumbe i Merauke, przy południowym wybrzeżu wyspy, na pograniczu indonezyjskiej Papui i PNG. Aż do początku XX wieku Marindowie (w starszej literaturze zwani Tugeri) urządzali regularne napady na papuaską ludność u ujścia rzeki Fly, a także na mieszkańców Wysp Cieśniny Torresa.

Żyjący w Górach Owena Stanleya (PNG) Anga, zwani też Kukukuku, którzy w całej wschodniej części wyspy mają dziś renomę zawodowych rabusiów i morderców, od pokoleń atakowali austronezyjskie wspólnoty Watut i Wampar zamieszkujące wybrzeże zatoki Huon (prowincja Morobe), doprowadzając nawet do trwałej eksterminacji niektórych osad etnicznego pogranicza. Z kolei lud Asmat (dorzecze Lorentz i Pulau na południu indonezyjskiej Papui), który co prawda nie urządzał dalekich wypraw, z powodu swojej wojowniczości nie

\footnotetext{
${ }^{15}$ W brytyjskiej części Nowej Gwinei pierwsze poważniejsze akcje władz kolonialnych zapobiegające wojnom międzyplemiennym, nastąpiły dopiero w latach 1954-1957, chociaż sporadyczne walki trwały tam jeszcze przez dwie dekady. W indonezyjskiej części wyspy zjawisko to, $\mathrm{w}$ jego nieskażonej postaci, trwało jeszcze dłużej. Ostatnią notowaną wojnę stoczyli tam we wrześniu 2006 roku górale Lani ze swymi zachodnimi sąsiadami Damal.
} 
dawał przystępu kolonialnym władzom holenderskim, długi czas sprawiał też trudności administratorom przybyłym z Indonezji.

Co było powodem owych wojennych eskapad? Po części rabunek - ten motyw wyraźnie występował w działaniach Anga, zaludniających wyższe partie gór, mało wydajne ekonomicznie. Łupili oni zamożniejsze osady rolników i rybaków wybrzeża. Jednak stałym elementem tych wypraw było zdobywanie uciętych głów pokonanych wojowników. Zdobyta w walce głowa powiększała splendor powracającego z boju mężczyzny, dawała mu też uznanie i społeczną pozycję. U Anga, podobnie jak w niektórych innych plemionach, dopiero zdobycie głowy innoplemieńca, na ogół w rytualnej bitwie, dawało mu prawo do ożenku, a tym samym do uznania go za pełnoprawnego uczestnika wspólnoty. Co więcej, zyskiwał przewagi nie tylko w życiu doczesnym, ale i pośmiertnym, gdyż dekapitacja przeciwnika była tu równoznaczna z jego wieczystym podporządkowaniem zwycięzcy. U Marindów istniał zwyczaj, według którego ujęty jeniec przed pozbawieniem go głowy zmuszany był do wyjawienia imienia. Imię to zapamiętywał zwycięski wojownik - na ogół młody chłopak, jeszcze przed ożenkiem - by następnie przekazać je swojemu pierworodnemu synowi ${ }^{16}$.

Kultura łowców głów nie narodziła się na Nowej Gwinei. Przyszła tam z północnego-zachodu, od strony Sulawesi i Wysp Sundajskich, których najstarsze etnosy aż do połowy XX wieku pielęgnowały zwyczaj gromadzenia głów pokonanych sąsiadów. Wspomniane grupy należą dziś językowo do rodziny austronezyjskiej, wydaje się jednak, że zwyczaj rytualnego odgławiania sięga czasów starszych i odnosi się do protopapuaskich mieszkańców terenu obecnej Indonezji.

Z kulturą łowców głów związany jest silny kult przodków, których sanktuaria znajdują się w rodowych siedzibach, lub też w obszernych domach zgromadzeń wspólnoty (ang. longhouse). Anga mumifikowali swoich zmarłych - szczególnie tych otoczonych za życia ogólnym szacunkiem - wędząc zwłoki w dymie spalonych krzewów. Procedura takiej mumifikacji trwała wiele dni, na ogół około miesiąca. Mimo rządowego zakazu z 1975 roku rytualna mumifikacja przodków jest tam nadal praktykowana, choć incydentalnie i dyskretnie.

Anga, podobnie jak kilka innych plemion „łowców głów”, gromadzili w domach wspólnoty także głowy swoich wodzów, zmarłych lub zabitych $\mathrm{w}$ walce. Według miejscowych wierzeń posiadanie głowy bohatera zapewnia „przelanie” jego męstwa, a także siły życiowej na aktualnego posiadacza. Ususzone głowy wybitnych wojowników były też traktowane jako swego rodzaju depozyt pomyślności plemienia, przekazywany kolejnym pokoleniom „kustoszy”.

Kolejną cechą wyróżniającą kultury „łowców głów” było znaczenie rytualnego kanibalizmu. W prekolonialnej Nowej Gwinei ludożerstwo - zarówno sakralne, jak i uprawiane z powodów praktycznych - było obyczajem dość powszechnym, ale w wojowniczych wspólnotach górskiego pasa przybrało ono

${ }^{16}$ Ofiary często zamiast własnego imienia mówiły oprawcom jakiekolwiek słowo - które później stawało się imieniem nowo narodzonego Marinda. W ceremonii nadania imienia potomkowi uczestniczyła też ususzona głowa pokonanego umieszczona między nogami młodego ojca. Głowę tę po oczyszczeniu z mózgu i chrząstek powlekano na powrót skórą zabitego. 
wymiar ważnego spoiwa społecznego. Wyprawy rabunkowe Anga i innych były też w przeważającej mierze wypadami po „długie świnie”, jak nazywa się ludzi w centralnej części wyspy. Ujętych w niewolę zabijano i spożywano w osadach zwycięzców. Motywy owego kanibalizmu były podobne jak w wypadku kolekcjonowania głów pokonanych - wspólne zjadanie zwłok jeńca było ważnym symbolem integracji lokalnej wspólnoty plemiennej.

Wyróżniającym artefaktem wspomnianych kultur były kamienne siekiery. Specjalnie gładzone, o wąskim, podłużnym ostrzu i długiej łopatce, równoważącej ciężar przedniej części topora, przytwierdzone były do drewnianego styliska włóknami drzew tropikalnych. Pierwsze egzemplarze tych narzęd zi dostały się w ręce białych w 1933 roku w okolicach Mount Hagen, na terenie obecnej prowincji Western Highlands. We wschodniej części tej prowincji, w dolinach rzek Wahgi i Jimi, działały od niepamiętnych czasów swoiste manufaktury, w których owe siekiery wykonywano. W wytwory tych neolitycznych fabryk zaopatrywano nie tylko najbliższe okolice, ale także plemiona żyjące w odległości kilkuset kilometrów, bliżej oceanu. Wszystko wskazuje na to, że owa dobrze zorganizowana sieć zaopatrzenia funkcjonowała bez większych zmian przez tysiące, a może dziesiątki tysięcy lat, aż do połowy XX wieku, kiedy to ingerencja białego człowieka zakłóciła działanie starych struktur wymiany. Kamienne siekiery zresztą przestały być potrzebne, gdyż wyparły je bardziej skuteczne narzędzia metalowe.

Nowogwinejski wynalazek w postaci kamiennych siekier zrewolucjonizował stosunki na wyspie. Topory tworzono bowiem nie tylko w wersji bojowej, lecz także - i to znacznie częściej - na potrzeby gospodarcze. W rękach sprawnego użytkownika narzędzie to było wystarczającym środkiem do pozyskiwania pni nawet dużych drzew - co wcześniej nie było możliwe. Otworzyło to droge do budowy większych konstrukcji drewnianych, jak chociażby wspomniane już domy wspólnoty (longhouse).

Istnienie manufaktur toporów nad Jimi i Wahgi oraz zasięg eksportu ich wytworów skłaniają do zastanowienia. Sugerują one istnienie - w odległej przeszłości, nieobjętej ani pisaną historią, ani nawet zmitologizowaną pamięcią żyjących pokoleń - wspólnot kulturowych na wyższym szczeblu technologicznego rozwoju niż ten zastany w momencie kolonialnej ekspansji. Porównanie $\mathrm{z}$ rozwojem precywilizacyjnych ${ }^{17}$ kultur rolniczych $\mathrm{w}$ innych częściach świata sugerowałoby podobny rozwój także tutaj, oczywiście pod warunkiem odpowiednio długiego czasu. W wypadku Nowej Gwinei warunek ten jest spełniony chodzi o okres rzędu 10 tys. lat dzielących nas od powstania rolniczych wspólnot „wyżynnej” części wyspy.

Nie znajdujemy tutaj jednak śladów dużych osad rolniczych, podobnych do tych z Mezopotamii (dolina Tygrysu), Chin (Huang Ho) czy Indii (baseny Indusu i Gangesu). Niewykluczone wszakże, że podobne duże i rozwinięte ośrodki jednak powstały. W drugiej połowie XX stulecia zainteresowanie uczonych wzbudził tzw. ambum, kamienna rzeźba wyobrażająca siedzące zwierzę,

\footnotetext{
${ }^{17}$ Cywilizację za profesorem Andrzejem Wiercińskim (2010) definiuję jako zurbanizowaną kulturę.
} 
prawdopodobnie kolczatkę. Rzeźba ta dowodzi wysokiego kunsztu artysty i nie ma odpowiednika we współczesnych kulturach etnicznych Nowej Gwinei, gdzie dominuje rzeźba drewniana, snycerka albo też surowa obróbka kamienia. Pochodzi sprzed 1,5 tys. lat p.n.e., odnaleziono ją w Enga, prowincji położonej dziś peryferyjnie w stosunku do administracyjnych centrów Papui-Nowej Gwinei, umiejscowionej wszelako w środkowym odcinku transnowogwinejskiego pasa językowego.

Podobnych rzeźb odnaleziono jeszcze kilka - w Enga i sąsiednich prowincjach śródgórskich. Być może w tej właśnie niszy ekologicznej istniała kultura wyższa, operująca doskonalszymi narzędziami i subtelniejszymi technikami obróbki kamienia. Czy zatem poprzednicy współczesnych Papuasów w zamierzchłych czasach byli w stanie budować kamienne domy? To pytanie zapewne na zawsze pozostanie w sferze spekulacji.

Kultura z Enga, nawet dysponując odpowiednim czasem rozwoju, nie mogła jednak rozwinąć się na podobieństwo kultur Mezopotamii czy Indusu, gdyż pozostając w skrajnej izolacji (góry otoczone tropikalnym lasem, brak dostępu do morza), musiałaby ulec stopniowej degradacji. Artefaktów podobnych do ambum na pewno spoczywa w ziemi znacznie więcej, ale na tak dużym i niedostępnym obszarze interioru wyspy, w ogarniętym anarchią młodym państwie postkolonialnym, jakim jest PNG, niemożliwe jest w tej chwili prowadzenie poważniejszych badań archeologicznych; niemożliwe jest nawet wytypowanie obszarów do potencjalnych wykopalisk.

Po twórcach rzeźby z Enga nie pozostał żaden ślad w pamięci ludów żyjących tam dzisiaj. Można więc przypuszczać, że ich rodzima kultura, słaba i bezbronna, padła ofiarą przesunięć demograficznych około $1000-500$ r. p.n.e. Nowi przybysze, prowadząc ekspansję na terenie wybrzeży (szczególnie u wybrzeża północnego), zmusili dotychczasowych mieszkańców tropikalnych lasów do ucieczki w głąb lądu, ku górskim dolinom. Z kolei uciekinierzy zdobyli tam i zniszczyli osady bardziej rozwiniętych technologicznie, lecz słabszych militarnie mieszkańców Enga, Jimi czy Wahgi, prawdopodobnie mordując wszystkich mężczyzn. W ten sposób przybysze z nizin bezpowrotnie zniwelowali zarysy kultury, której istnienia dopiero teraz możemy się domyślać.

Ale kim byli owi pierwotni najeźdźcy, którzy zawładnęli nowogwinejskim wybrzeżem? Byli to przybysze z zachodu, wspomniani już Austronezyjczycy. Na Nowej Gwinei nie zagrzali długo miejsca, podobnie jak Normanowie na Wyspach Brytyjskich, wszelako pozostawili po sobie ślady do dzisiaj, chociażby $\mathrm{w}$ postaci kilku austronezyjskojęzycznych grup, rozsiedlonych na różnych odcinkach wybrzeża, a także na przybrzeżnych wyspach. Na zachodnim krańcu półwyspu Ptasia Głowa rozmieściły się plemiona grupy Waigeo, dalej na południe, na półwyspie Bomberai mamy Irarutu i Kuri, na wschód od nich, nad zatoką Cenderawasih (dawniej zwanej Geelvink), żyją Wandamen oraz Iresim. W PNG największym zespołem etnosów austronezyjskich są ludy zatoki Huon. Z południowej strony lądu, nad Zatoką Papuańską, znajdziemy Mekeu, Sinaugoro i Buhutu. Spośród ludów wysp przybrzeżnych warto wymienić mieszkańców 
wyspy Biem, położonej $70 \mathrm{~km}$ od głównego lądu, na odcinku granicy między prowincjami Wschodniego Sepiku i Madang.

Austronezyjczycy stanowią chronologicznie ostatnią warstwę osadniczą, która składa się na etniczną panoramę autochtonicznej Nowej Gwinei.

Kultura materialna wyspy oparta jest na ogólnie dostępnych materiałach rodzimych: kamieniu, kości, muszli na rejonach przybrzeżnych, ale przede wszystkim na drewnie. Drewniana wytwórczość, począwszy od dzieł architektury, skończywszy zaś na drobnych przedmiotach codziennego użytku, choć zróżnicowana regionalnie pod względem stylu i bogactwa ornamentyki, nadaje kulturze wyspy jednolitą i rozpoznawalną cechę.

Ogólnie rzecz biorąc, bogatsze w formy są etniczne kultury północy, która znalazła się w kręgu intensywniejszych wpływów Austronezyjczyków. Rdzennie papuaskie kręgi wytwórcze reprezentują na ogół dzieła uboższe formalnie oraz skromniejsze w ekspresji. Nie jest to jednak reguła sztywna, gdyż na ten podstawowy podział zachodzą jeszcze różnice między poszczególnymi lokalnymi wspólnotami etnicznymi.

Można wyróżnić dwa większe etnosy lub ich zbiory reprezentujące kulturę materialną rozbudowaną formalnie i estetycznie dojrzałą. Pierwszy z nich to rejon basenu dolnego Sepiku (prowincja East Sepik w PNG). Mieszka tam kilka większych oraz kilkadziesiąt mniejszych grup językowo-etnicznych. Do większych należy zaliczyć Arapeszów, dzielących się na trzy podgrupy: Bumbita, których wioski znajdują się pomiędzy wybrzeżem Oceanu Spokojnego a granią Gór Księcia Aleksandra, Bukiyip, górali z dolin południowych stoków, oraz Mufian mieszkających na zachód od Mapriku, lokalnego ośrodka miejskiego. Abelamowie, sąsiedzi Arapeszów, żyją również w Górach Księcia Aleksandra. Nad Yuat, południowym dopływem Sepiku, znajdziemy Mundugumorów, znanych dzisiaj bardziej pod etnonimem Biwat. Na zachód, w górę rzeki, do większych etnosów należą też Czambri, których w polskiej literaturze fachowej od czasów Malinowskiego zwie się Czambulijczykami.

Rejon Sepiku uznawany jest za najbogatszy estetycznie w skali całej Nowej Gwinei. Za jego wizytówkę można uznać tzw. domy duchów (haus tambaran $\mathrm{w}$ tok pisin). To lokalne wydanie znanych na całej wyspie domów wspólnoty lub domów zgromadzeń mężczyzn. Arapeski haus tambaran okolic Mapriku jest jednak w większym stopniu „śswiątynią" niż „zborem”.

Upowszechnione w literaturze światowej określenie haus tambaran może mylić. Ogólnym w PNG określeniem ducha, w tym wypadku ducha miejsca, jest masalaj. Duchy te związane są raczej z konkretnym locum w postaci kamienia, jeziorka, połaci lasu czy uroczyska niż z czczącym go rodem lub plemieniem. Lokalna wspólnota krwi, żyjąca w pobliżu mieszkania ducha, może go jednak obłaskawić i oswoić - i w tym sensie uważać za ducha rodu. Masalaj, niezadowolony, może jednak zawsze wypowiedzieć swoje łaski i zwrócić się przeciw ludziom. Termin tambaran oznacza natomiast całość obrzędów związanych z duchami przodków, stosuje się je też na oznaczenie tajemnicy. W tym sensie haus tambaran można przetłumaczyć jako „dom obrzędu” czy też „dom misterium”. 
Haus tambaran jest centralną budowlą każdej większej arapeskiej wioski w okolicy Mapriku. Buduje się go w pobliżu agehu, placu zgromadzeń wioskowych i centralnego miejsca życia wspólnoty. W tym sensie haus tambaran jest domem całej społeczności, ale nie każdy, nie zawsze i nie w tym samym stopniu ma do niego dostęp.

Budowa „domu obrzędu” jest dla wioskowej wspólnoty przedsięwzięciem, do którego przygotowania mogą trwać nawet kilkadziesiąt lat. Do ich budowy Arapesze używają najdorodniejszych i najroślejszych drzew, które wybiera się i przeznacza do tego celu już w pierwszych latach ich wzrostu. Wybiera się drzewa z gatunków o najtwardszym drewnie: kwila i garamut (oba gatunki zwane są „drzewami żelaznymi”). To nie jedyne ograniczenie, można użyć wyłącznie drzewa rosnących w „miejscach masalajowych”. Opiekunom przeznaczonych na budulec drzew chodzi w tym wypadku o to, aby wzrostu drzewek nie skaził kontakt z siłami nieczystymi: opieka ducha miejsca ma je od tego uchronić. Każde pojedyncze drzewo należy więc do innego rodu związanego z danym masalajem, i ród ten ma obowiązek doglądania jego wzrostu. Ponieważ cykl wzrostu „drzew żelaznych" trwa dłużej niż jedno pokolenie, obowiązek opieki przechodzi z ojca na syna. Sam transport ściętych drzew trwa do dwóch tygodni.

Do budowy „domu obrzędu” stają w osadzie wszyscy zdolni do pracy mężczyźni, ponadto zaprasza się do niej wybranych mężczyzn z sąsiednich wiosek. Nie ma tutaj „architekta” ani nadzorcy budowy. Zespół snycerzy i malarzy belek naradza się przed rozpoczęciem każdej fazy budowlanej. O wysokości świątyni decyduje wzrost najwyższych drzew przeznaczonych na osie konstrukcji. O rozpoczęciu budowy decyduje jednak wódz lokalnej wspólnoty, ogłaszając ten moment biciem w garamut, ceremonialny bęben. Istnieje także wewnętrzna organizacja zespołu robotników, którzy dzielą się na artele (tj. moiety, czyli uzupełniające się połowy plemienia) według podziału na totemy. Podczas gdy jedną grupę stanowią „biali”, czyli przynależni do totemu białej papugi, drugą tworzą "czarni" z totemu jastrzębia. Wizerunki totemicznych zwierząt często wieńczą szczyty ukończonych świątyń.

Dwupodział występuje także w wyodrębnianiu grup sal i awar, czyli „starszych" i „młodszych braci”. „Starsi bracia” tworzą uprzywilejowany cech rzeźbiarzy i malarzy. „Młodsi” to niewykwalifikowana siła robocza.

Wznoszenie „domu obrzędu” planuje się zazwyczaj na okres zbierania plonów, aby nikomu z budujących nie zabrakło pożywienia. "Starszym braciom” pożywienie to sporządzają wyłącznie mężczyźni, aby pozbawić artystów, odpowiedzialnych za tworzenie kluczowych, „wrażliwych” sakralnie elementów świątyni, nawet pozoru kontaktu z kobietą w okresie menstruacji. Ich nieczystość mogłaby przejść na wykonywane przez nich dzieło - a to zwyczajowe prawo arapeskie uznaje się za wielkie wykroczenie. Dlatego „starsi bracia” są grupą otoczoną szczególnym tabu. Miejsce ich pracy odgradza się specjalnym płotem, aby uniemożliwić im kontakty z osobami z zewnątrz, a także zasłonić przed niepowołanym spojrzeniem. Także młodsi poddawani są pewnym tabuistycznym rygorom: do pracy w tym zespole dopuszcza się jedynie mężczyzn po inicjacji. 
Każdy artel ma w swoim składzie „brygadowego” czarownika, którego jedynym zadaniem jest troska o to, by nikt z zespołu nie utracił wewnętrznej mocy, niezbędnej przy pochłaniającej energię budowie.

Do budowy „domu obrzędu” nie wolno używać gwoździ ani nawet drewnianych kołków. Belki konstrukcji nośnej łączy się ze sobą za pomocą lian i włókien roślinnych. Niedopuszczalne jest też nacinanie belek na zrąb. Mimo pozornego braku ogólnego nadzoru rzadko się zdarza, aby tak powstający budynek świątynny uległ zawaleniu. Kiedy jednak to nastąpi, zespół robotników natychmiast szuka winnego. Odnalezionego winowajcę odsyła się z budowy. To jedyna kara: Arapesze unikają tu drastycznych sankcji, gdyż uważają, że czas spędzony przy budowie świątyni jest czasem świętym, którego nie mogą zakłócać żadne spory.

Więźbę dachową pokrywa się liśćmi drzewa marata.

Kiedy "dom obrzędu” uznaje się za ukończony, do jego wnętrza spuszcza się ze szczytu ukręcony z lian powróz, do którego przywiązane są kości przodków oraz szczątki totemicznych zwierząt. W świątynnej przestrzeni zwisają one na konstrukcji o kształcie trójgraniastego stożka.

Gotowy budynek, z charakterystycznie wygiętą do środka kalenicą dachu, przybiera kształt podobny do siodła albo łodzi. Szczególnie efektownie wygląda szczyt, smukły i wznoszący się wysoko, z reguły ozdobiony totemiczną rzeźbą albo wizerunkiem słońca. Ten element jest dodatkiem dwudziestowiecznym, narodzonym pod wpływem estetyki europejskiego Zachodu, gdyż starych „domów obrzędu” na ogół nie wieńczono żadnymi rzeźbami ani wizerunkami. Podziw wzbudza też widok fasady. Czołowa ściana zewnętrzna, nachylona do przodu, tworzy sylwetkę, po której już z daleka można poznać przeznaczenie budynku. Wychylenie od pionu wzrasta w miarę wysokości, zatem szczytowa część frontonu wysunięta jest znacznie poza podstawę domu.

Na frontonie wyobrażony jest świat przodków. Ich drewniane postacie przedstawione są hieratycznie bez uwzględnienia naturalnych proporcji. Są statyczne, a wyrzeźbione twarze pozbawione są wyrazu. Zwracają uwagę nienaturalnie duże oczy. Wizerunki przodków noszą odznaki przynależne wodzom: rzeźby zdobi się ornamentem z muszelek, ich twarze pomalowane są też we wzory, jakimi zdobi się plemiennego dowódcę wyruszającego na wojnę. Ich głowy wieńczą pióropusze z piór białej papugi.

Powyżej poziomu z przedstawieniami duchów przodków maluje się stylizowane wizerunki zwierząt: psów, nietoperzy, jaszczurek czy też owadów. Nad nimi, w części szczytowej frontonu, umieszcza się kilka kolejnych figur przodków, których twarze zasłaniają maski. Całość frontonu tworzy efektowną, kolorową płaszczyznę pokrytą malaturami na powierzchni 100-200 $\mathrm{m}^{2}$. Malunki tworzone są farbami naturalnymi, uzyskanymi z minerałów albo barwników roślinnych. Kanoniczne kolory to biały, czarny, żółty i ceglastoczerwony. Wizerunki maluje się za pomocą szpatułek z trzciny cukrowej, których końce pomocnicy artystów przed użyciem żują, aby je zmiękczyć. Drobniejsze szczegóły uzupełniało się pędzelkami z ptasich piór, dziś już powszechnie wypartymi przez pędzle kupowane w sklepach. 
Od góry fronton zabezpieczony jest przez „tympanon” wykonany z maty, od dołu opiera się on na bogato zdobionej belce fryzowej (bueń). Również na niej umieszcza się rzeźbione wizerunki duchów przodków. Dawniej umieszczano tu czaszki. Tradycyjny bueń wykonuje się z dwóch połówek osobnych pni, które dopiero po dokładnej obróbce łączy się w jedną belkę. Każdą z tych połówek ociosuje i rzeźbi inny artel ciesielski. Z belki fryzowej zwisa inna mata, dwubarwna, o zygzakowatym geometrycznym ornamencie. W macie znajduje się niski otwór, przez który można wejść do środka.

Wstęp do wnętrza świątyni, podobnie jak uprawa jamów, zastrzeżony jest jedynie dla mężczyzn po inicjacji. Wejście do „domu obrzędu” jest niskie, a wchodzący muszą się pochylić, aby wejść do środka. Symbolizuje bowiem drogę do łona matki, symbolu ważnego w rodzimej religii Arapeszów, kórych naczelną boginią jest Pramatka Aczakoik. W środku znajdujemy całą galerię drewnianych posągów ludzkich i zwierzęcych. Wszystkie są pomalowane. Wizerunki ludzkie, z rysami twarzy wymodelowanymi na charakterystyczny kształt litery $\mathrm{T}$, przedstawiają posągi przodków, którym obecni w świątyni wierni składają ofiary, prosząc o pomyślność dla siebie i rodziny. Umieszczono tu także święte maski uplecione $\mathrm{z}$ gałązek drzewa rotang. Na wolnych miejscach przy ścianach spoczywają egzemplarze broni używanej w wojennych wyprawach: bojowe topory, włócznie i łuki. Przechowuje się tu również instrumenty muzyczne, w szczególności święte flety, używane w najbardziej uroczystych i tajemniczych momentach religijnych ceremonii. Ich nazwa, bueń, pochodzi od wspomnianej belki fryzowej świątyni. Obok fletów znajdujemy też kilka rodzajów ceremonialnych bębnów.

„Dom obrzędu” jest więc nie tylko sanktuarium, lecz także rodzajem muzeum, składnicą przedmiotów, które w różny sposób wiążą się z sakralnym wymiarem arapeskiego życia i które tutaj, we wnętrzu świątyni, znajdują schronienie przed niepowołanym spojrzeniem.

Oryginalny kształt tych świątyń wskazuje na ich pochodzenie. Bardzo podobne budynki stawia się do dzisiaj na terenie Indonezji, chociażby u Bataków z Sumatry albo u Toradża na Sulawesi (tongkoman). Oba wspomniane ludy, reprezentujące austronezyjską grupę językową, należą do jednych ze starszych etnosów sundajskich archipelagów. Nie są to świątynie, ale domy mieszkalne albo gospodarcze, lecz również i w takich przypadkach pełnią funkcje parasakralne. Podobnie jak arapeskie, sundajskie „domy duchów” są bogato zdobione. Jest tutaj także miejsce na figury przodków albo stylizowane na wizerunki zwierząt (bawół, wąż albo krokodyl) posągi bóstw. Umieszczanie tych wizerunków ma wspierać pomyślność mieszkającej w domu rodziny; jeśli jest to spichlerz, stylizowane postacie przodków strzegą zgromadzone wewnątrz zbiory.

Arapescy twórcy „domów obrzędu” nie uważają się za artystów, gdyż w ich własnym pojęciu nie tworzą rzeczy pięknych. Pojęcie piękna nie występuje w papuaskiej kosmologii, obecny w języku tok pisin zwrot nais pela lu oznacza coś ładnego, bez głębszych konotacji. Cieśle i malarze arapeskiej świątyni nie tyle tworzą, ile odtwarzają rzeczywistość - tak jak sami ją widzą (patrz też: Tuzin 2000, 2011). 
Na przeciwległym brzegu wyspy, nad nizinnymi brzegami Morza Arafura (wybrzeże Casuarina), rozmieszczone są siedziby ludu Asmat. Etnos ten znany jest jako wytwórcy drewnianych, stojących rzeźb, pełnopostaciowych przedstawień postaci ludzkich. Podobnie jak u Arapeszów, wyobrażają one duchy przodków. Asmatowie wierzą, że ludzie powstają i rodzą się z drzew, podobnie po śmierci duch człowieka wraca do ,jego" drzewa. Rzeźby duchów nie wyczerpują inwencji tego ludu, który wydaje z siebie pokolenia znakomitych snycerzy. Zarówno pełnopostaciowe rzeźby, jak i zdobienia Asmatów zachowują wyrafinowane, poza rejonem Sepiku nieznane u innych ludów wyspy formy, zadziwiające dynamiką kształtu lub też ażurową subtelnością ornamentacji.

Asmatowie, którzy jak inni Papuasi są rolnikami, zachowali w kulturze wiele wspomnień o dawniejszym okresie swojej egzystencji. Żyjąc w bliskim sąsiedztwie lasu, czerpią zeń ekonomiczne korzyści. Las jest także ważnym elementem ich kosmologii. Jeszcze więcej kulturowych związków z tropikalnym lasem mają ich sąsiedzi, żyjący w głębi lądu, w górnych biegach rzek, przy których Asmatowie założyli swoje wioski. Godni wspomnienia są Korowai, którzy z niezwykłą sprawnością budują drewniane domy w koronach drzew. Domy te, dostępne za pomocą drabinek uplecionych z lian, umieszczone bywają na znacznej wysokości, nierzadko dochodzącej do $45 \mathrm{~m}$. Utrzymują je wysokie pale, które wszelako nie dźwigają całego ciężaru domu wraz z jego mieszkańcami - ciężar ten za pomocą bocznych konstrukcji rozłożony jest także na inne strony. Domy Korowai zresztą nie są ciężkie, ich ażurowy szkielet pokrywa niewiele ważący dach z liści palmowych.

Można przypuszczać, że Korowai nie wspięli się ze swoim wynalazkiem na wysokie i trudno dostępne poziomy lasu, lecz zasiedlali je już wcześniej, zanim poznali sztukę budowy domów. Sztukę tę ich przodkowie przejęli około 10 tys. lat temu wraz z rozwojem kultur rolnych na Nowej Gwinei. Jako lud leśny dostosowali więc nowo poznaną technikę budowlaną do rodzimego, tradycyjnego sposobu życia. Warto pamiętać, że jeszcze do niedawna w podobny sposób budowali swoje domostwa Aetowie, Negryci zamieszkujący archipelag Filipin, głównie zaś północne rejony wyspy Luzon.

Porównując kultury etniczne ludów dolnego i górnego biegu rzek wpadających do Morza Arafura z analogicznymi kulturami etnosów basenu Sepiku, można dostrzec jeszcze jedno, zasadnicze podobieństwo. Bogactwo form i estetyczna różnorodność, a także wyraźne relikty archaicznych form kulturowej ekspresji wskazują na istnienie w jednym i drugim regionie niewygasłych etnicznych substratów, na które dopiero nałożyły się kultury późniejsze. Ten stratygraficzny układ etniczny, w którym można wyróżnić kolejne wpływy następujących po sobie ludów, typowy dla obszarów pogranicza, nie jest czymś zwyczajnym na Nowej Gwinei, gdzie większość plemion reprezentuje raczej jednorodny pod względem etnicznym styl kulturowy.

Można to objaśnić statycznością zasiedlenia oraz izolacją, pamiętajmy również, że najazdy, które się tu w prehistorii odbywały, z reguły skutkowały eksterminacją przynajmniej męskiej części populacji (co prawdopodobnie przypadło 
w udziale uczestnikom wspomnianej już kamiennej kultury z Enga). Plemiona, które osiedlały się na miejscu pokonanych, urządzały więc po swojemu zdobyte tereny. Rejon Sepiku, a także obszar zasiedlenia ludu Asmat i ich najbliższych sąsiadów, był - jak widać - na tyle ludny i bogaty pod względem kultury, że kolejni zdobywcy, rezygnując z eksterminacji, z czasem zasymilowali się z podbitą nacją.

\section{Nowa Zelandia i mniejsze wyspy Oceanii}

Opisywany tutaj obszar Oceanii składa się z trzech wielkich regionów: Melanezji, Mikronezji i Polinezji. Z obszaru tego wyłączyliśmy należącą do Melanezji Nową Gwineę z racji osobnego, rolniczego charakteru jej tradycyjnej kultury etnicznej. Pozostałe terytoria łączy ze sobą morski typ kultury ludów morza, znajdujący odbicie zarówno w tradycyjnej kosmologii, estetyce i obyczajowości, jak i strukturze społecznej, a także gospodarce rodzimych etnosów.

Do Melanezji zaliczamy wyspy i archipelagi rozmieszczone na wschód od Nowej Gwinei. Najbliżej tej wyspy znajdziemy archipelagi d'Entrecasteaux oraz Luizjady, na północ od nich - Nową Brytanię, Nową Irlandię i Wyspy Admiralicji, rozległym łukiem okalające Morze Bismarcka. Dalej na wschód, oddzielona rowem oceanicznym, leży wyspa Bougainville, należąca już do grupy Wysp Salomona. Wszystkie wspomniane dotąd wyspy należą do Papui-Nowej Gwinei. Większość archipelagu Wysp Salomona stanowi niepodległe państwo pod tą samą nazwą. Kolejnymi melanezyjskimi archipelagami-państwami są Vanuatu (dawniej zwane Nowymi Hebrydami) i Fidżi. Samotna wyspa i jednocześnie państwo Nauru leży pośrodku Basenu Melanezyjskiego oddzielającego Melanezję od Mikronezji. Obszarem politycznie zależnym od Francji jest Nowa Kaledonia; inne terytorium francuskie, Wallis i Futuna, leży już w pasie przejściowym pogranicza z Polinezją.

Mikronezja (nazwana tak od małej powierzchni składających się na nią wysp) leży na północ od Melanezji. Zaliczamy do niej - patrząc od wschodu - Palau, republikę Mikronezji, Wyspy Marshalla oraz Kiribati. Wszystkie wymienione terytoria stanowią niepodległe państwa. Mariany Północne są kolonią - oficjalnie "terytorium stowarzyszonym" - Stanów Zjednoczonych.

Listę obszarów Polinezji - ze wszystkich trzech najbardziej rozległego otwiera Polinezja Francuska, ,terytorium zamorskie" Francji, z największą wyspą Tahiti, należącą do archipelagu Wysp Towarzystwa. Do Polinezji Francuskiej należą też archipelagi Tuamotu, Tubuai oraz Markizy. Bardziej na zachód położone są Tuvalu i Tonga, stanowiące jednocześnie niepodległe państwa. Leżący pomiędzy nimi archipelag Samoa w części zachodniej jest niepodległą republiką, we wschodniej - terytorium Stanów Zjednoczonych. Rozległy archipelag Hawajów, leżący w północnej partii Oceanu Spokojnego, jest stanem USA; Pitcairn należy do Wielkiej Brytanii, a Wyspa Wielkanocna do Chile. Osobno należy wymienić niepodległą Nową Zelandię, która składa się z Wyspy Północnej oraz 
Wyspy Południowej. Do tego państwa należą też archipelagi Tokelau i Wyspy Cooka. Wśród terytoriów Oceanii Nowa Zelandia stanowi wyjątek z powodu swojej wielkości przekraczającej sumę powierzchni wszystkich pozostałych wysp (nie licząc Nowej Gwinei), a także z racji położenia na skrajnym południu Polinezji.

Pozostałe archipelagi, na które składa się zazwyczaj od kilku do kilkunastu, rzadziej kilkudziesięciu wysp i wysepek, są niewielkie, ich lądowa powierzchnia wynosi zaledwie od kilkudziesięciu do kilkuset kilometrów kwadratowych, co oznacza rząd wielkości dużego europejskiego miasta. Jedynie wyspy Archipelagu Bismarcka, Wyspy Salomona, Fidżi i Hawaje dochodzą do rzędu wielkości 20-30 tys. $\mathrm{km}^{2}$ (30 tys. km² odpowiada powierzchni Belgii). Archipelagi te rozrzucone są na oceanicznej osi o przeciętnej długości 2-3 tys. km. Oddziela je od siebie ocean; dystans pomiędzy poszczególnymi z archipelagów wynosi 2-3 tys. km, a nawet - jak w przypadku Hawajów - do 5 tys. km.

Już same te liczby dają wyobrażenie o charakterze całego regionu, który można traktować raczej jako luźną federację niewielkich skrawków lądu w głębi Pacyfiku. Zrozumiałe, że jedynym komunikacyjnym łącznikiem, który w przeszłości scalał ten region, była żegluga morska. To zdeterminowało kulturę Oceanii.

Mniejsze wyspy są pochodzenia wulkanicznego lub powstały jako atole koralowców (te ostatnie są typowe dla Mikronezji). Wyspy koralowe są płaskie, krajobraz wysp powstałych na skutek erupcji wieńczy widok stożka wygasłego bądź czynnego wulkanu. I tu, i tam większość powierzchni porasta tropikalna roślinność, przy czym na wyspach wulkanicznych las deszczowy pnie się po stokach aż do granicy wysokości wegetacji. Wybrzeża okalają plaże, kamieniste bądź piaszczyste.

$\mathrm{Na}$ tej to naturalnej scenie rozgrywały się dzieje człowieka, które z braku pisanej spuścizny przepadły dla pamięci współczesnych pokoleń. Jedno można powiedzieć na pewno: właściwym „teatrem dziejów” było tu zawsze morze, zaś ląd jako taki, który gdzie indziej jest miejscem wędrówek ludów, wojen i rewolucji, stanowił tylko przystanki owych prehistorycznych akcji.

Z faktu tego wypływa kolejna konsekwencja: charakter i porządek zasiedlenia Oceanii przez człowieka. Na początku tego rozdziału zakreśliliśmy historię kolonizacji regionu przez Austronezyjczyków, autochtoniczną ludność Oceanii. Naszkicowane w kilku słowach dzieje osadnictwa, mieszczące się w schemacie „od - do" oraz lepiej lub gorzej sprecyzowanej chronologii, robią wrażenie logicznych i zdeterminowanych, zwłaszcza gdy czytelnik będzie śledzić postępy kolonizacji z mapą w ręku.

Rzeczywistość nie wyglądała jednak tak prosto. Pamiętajmy, że mamy do czynienia zarówno z rozległymi ramami czasowymi (rząd tysięcy lat), jak i z wyjątkowo dużą powierzchnią oceanu, którą wcześni żeglarze, dysponujący mało zaawansowanymi technicznie środkami transportu, przemierzali miesiącami bez wiedzy, dokąd dopłyną. Na zastany z perspektywy współczesnego obserwatora efekt ludzkiej kolonizacji musiały się więc złożyć liczne nieudane i chaotyczne, czasem zaś wręcz przypadkowe próby penetrowania Pacyfiku. 
O tym wszystkim musimy pamiętać, zanim - myśląc o rodzimych etnosach Oceanii - zaczniemy operować kategoriami „kręgów kulturowych”. Kręgi takie tworzą się dopiero w sytuacji, gdy komunikacja, morska bądź lądowa, jest już zjawiskiem ustabilizowanym. Dopiero bowiem stabilizacja, i to w dłuższym okresie, pozwala międzyetnicznej komunikacji odegrać rolę czynnika kulturotwórczego.

W przypadku Melanezji komunikację taką zdeterminowały czynniki atmosferyczne. Monsuny wiejące każdego stycznia z zachodu na wschód - od Morza Jawajskiego ku Morzu Arafura, zatoce Karpentaria i Cieśninie Torresa - niejako same nadawały kierunek morskiej migracji. Płynąc z wiatrem, pierwsze pokolenia austronezyjskich żeglarzy mogły dostać się jeszcze dalej, do basenu Morza Koralowego, a nawet do Morza Fidżi, znacząc w ten sposób późniejsze granice zasiedlenia Melanezyjczyków. Dalej jednak rozciągał się ocean, jak się wydaje, możliwy do przebycia tylko w dużej, solidnej łodzi z bocznymi wysięgnikami, typowej dla Polinezyjczyków. Jak już wiemy, ci ostatni opanowali wschodnie obszary Pacyfiku dopiero około XIII stulecia.

Czy jednak, docierając do najdalszych wysp oceanu, byli pierwszymi ludźmi, którzy się tam pojawili? Na to pytanie nie można odpowiedzieć prostym „tak”. Wśród około tysiąca moai ${ }^{18}$, znajdujących się do dziś na Wyspie Wielkanocnej, znajduje się niepodobny do innych posąg tukuturi. Kształt głowy postaci i rysy jej twarzy, przypominające filipińskiego Negrytę albo rzeźbione postacie Olmeków, kontrastują z długogłowymi i długonosymi obliczami moai. Klęcząca postawa może wskazywać, że figura przedstawia pokonanego wodza, upokorzonego przez polinezyjskich zwycięzców.

W jaki sposób Negryci, niedysponujący łodziami, a już na pewno takimi, które zdołałyby stawić czoła wysokim falom Pacyfiku, mogliby dostać się na Wyspę Wielkanocną? Wyczerpująca odpowiedź na to pytanie wykracza poza temat tej pracy. Pewną wskazówką mogą być wyniki badań DNA, przeprowadzone w 2016 roku przez zespół brytyjskich, amerykańskich oraz indonezyjskich genetyków ${ }^{19}$ na szczątkach kobiecych z Vanuatu i Tonga. Kobiety te żyły 3 tys. lat p.n.e. w kręgu wspomnianej już kultury Lapita. Badania wykazały ich bezpośrednie pokrewieństwo ze współcześnie żyjącymi ludami Azji Południowo-Wschodniej: Atayal na Tajwanie oraz Kankanaey na filipińskiej wyspie Luzon. Brak tam natomiast śladów genotypów melanezyjskich.

Okazuje się więc, że pierwsza fala austronezyjskich osadników, około 3 tys. lat p.n.e., w stosunkowo krótkim czasie przepłynęła olbrzymi dystans dzielący wyspy Morza Filipińskiego od centralnych archipelagów Polinezji (Vanuatu i Tonga, ośrodek kultury Lapita). W tej drodze na wschód śmiali żeglarze minęli Nową Gwineę, opływając ją od strony północnej, oceanicznej i nie wchodząc w związki genetyczne z jej mieszkańcami. Jakaś odnoga tej fali trafiła jednak na obszar Archipelagu Bismarcka, gdzie doszło do amalgamacji obu etnosów Austronezyjczyków i melanezyjskich autochtonów. Stamtąd dopiero po jakimś

\footnotetext{
${ }^{18} \mathrm{O}$ tych obiektach piszemy niżej.

${ }^{19}$ Por. Genomic insights into the peopling of the Southwest Pacific (2016). Nature, 538, 510-513.
} 
czasie ich potomkowie, z pewnością wykorzystując wynalazek łodzi z wysięgnikami, również popłynęli na wschód, śladem pionierów, i w Polinezji zmieszali się z wcześniejszymi przybyszami. Negroidalny w typie urody wódz, wyrzeźbiony w figurze tukuturi na Wyspie Wielkanocnej, mógł więc być reprezentantem drugiej po Austronezyjczykach, melanezyjskiej już fali osadniczej, która na ulepszonych łodziach zdołała dotrzeć dalej niż jej prekursorzy. Otóż na Wyspie Wielkanocnej być może właśnie ta ludność, w XIII wieku, uległa najazdowi, jednakowoż zdobywcy reprezentowali tam nie pierwszą, ale już drugą falę ekspansji austronezyjskich żeglarzy.

Wspomniane moai to po dziś dzień obiekt nieustających kontrowersji. Cel stworzenia z wulkanicznego tufu prawie 900 wysokich, czasem gigantycznych rozmiarów ludzkich postaci nadal nie został w pełni wyjaśniony, aczkolwiek najbardziej przekonuje hipoteza mówiąca, że chodzi tu o wyobrażenie rodowych przodków. Przeznaczeniem każdego z moai (nie wszystkie zdążono ustawić) było, jak się wydaje, patronowanie i straż nad okolicą z wysokości kamiennej platformy ahu. Olbrzymią większość moai ustawiono wzdłuż wybrzeża, być może w miejscach należących do danego klanu. Zróżnicowanie wysokości zarówno platform, jak i posągów mogłoby być tutaj wyrazem zróżnicowanej społecznie pozycji konkretnych rodów bądź nawet jednostek.

Te kolosalne kamienne konstrukcje, wymagające skoordynowanej pracy setek robotników, świadczą o wysokim stopniu społecznej organizacji żeglarskich wspólnot sprzed tysiąca lat. Podobnie imponujące i zagadkowe założenia odnajdujemy na odległej od Wyspy Wielkanocnej Mikronezji. We wschodniej części tego archipelagu, na Ponape, leżą bazaltowe ruiny Nan Madol, ośrodka władzy $\mathrm{z}$ końca XII wieku. To założenie protomiejskie rozwijało się już w IX-X wieku. Znamy dokładną datę jego upadku: zniszczono je w 1628 roku na skutek najazdu rywalizującej dynastii. Dziś część tych ruin zagarnęło morze.

Podobnego rodzaju, choć mniejsze kamienne założenie urbanistyczne znajduje się na wyspie Lelu, leżącej na wschód od Ponape. Leluh - bo tak nazywają miejscowi to miejsce - zbudowano później od Nan Madol, w XIV albo XV wieku. Również ten ośrodek władzy królewskiej został z czasem opuszczony.

Zdolność do tworzenia form protocywilizacyjnych nie dziwi, jeśli zważymy, że mamy tu do czynienia z wysoko zorganizowanymi społecznościami ludów morza. Etnosy te były społecznościami hierarchicznymi, zorganizowanymi na sposób feudalny, z często występującym modelem króla-kapłana, stojącego na szczycie społecznej drabiny. Zastanawiać może jedynie, dlaczego takie założenia jak Nan Madol, Leluh czy megality z Wyspy Wielkanocnej przepadły bez pamięci. Przepadła nie tylko znajomość rongorongo, pisma Rapa Nui (rodzima nazwa Wyspy Wielkanocnej), nie zadbano też o przekaz ustny dokumentujący wydarzenia $\mathrm{z}$ przeszłości. $\mathrm{W}$ rezultacie $\mathrm{w}$ momencie przybycia pierwszych białych mieszkańcy wyspy nie potrafili wyjaśnić, kto stawiał owe imponujące założenia i dlaczego je porzucono.

Być może przyczyna tkwi w tym samym czynniku, który sprawił, że przy podobnym stylu życia codziennego - tak bardzo różnią się między sobą 
poszczególne sposoby budowania domów wyspiarzy Oceanii. Ci nomadzi wodnej pustyni, którzy potrafili oddalać się o tysiące kilometrów od rodzinnych chat, $\mathrm{u}$ siebie, na miejscu, nie odczuwali większej potrzeby międzyplemiennej wymiany idei. Ich kultury etniczne pozostały więc względnie izolowane, chociaż oni sami nie stronili od poznawania (czytaj: podbijania) bliższych i dalszych sąsiadów. Kiedy więc dochodziło do podboju, nieważne, czy ze strony innego plemienia, wrogiego klanu, czy też rywalizującej dynastii, jego efektem stawało się z reguły zniszczenie kulturowego dorobku pokonanych. Zwycięzcy nie mieli ambicji przejmowania wzorów życia od ludzi, których głowy rytualnie ścinano po wygranej bitwie.

Obszar Melanezji pod względem etnicznym bliższy jest wczesnym, archaicznym warstwom osadniczym. Melanezyjczycy różnią się od Mikronezyjczyków i Polinezyjczyków także pod wglądem rasowym: przeważa wśród nich typ ciemny, niespotykany wśród bardziej jasnoskórych ludów otwartego oceanu. Pewna domieszka typu ciemnego wśród mieszkańców centralnych wysp Polinezji jest echem wspomnianej już, wtórnej inwazji, podjętej ze strony ludów austronezyjskiej. Badania DNA wykazują, że Polinezyjczycy o ciemniejszej karnacji są potomkami przybyłych z zachodu żeglarzy oraz polinezyjskich kobiet.

Śladów obecności ludów nieaustronezyjskich znajdziemy na Oceanii więcej. Nawet na Nowej Zelandii, w kolejnym miejscu, wydawałoby się, odciętym od reszty świata, w oralnej spuściźnie Maorysów zachowały się wiadomości o rdzennych mieszkańcach obu wysp, których zastali przybyli tam Polinezyjczycy. Analiza rodowych legend pod kątem trwania cyklu pokoleń wskazuje, że jeszcze w końcu XVI wieku ostatni przedmaoryscy mieszkańcy Nowej Zelandii, Waitaha - jak nazywają ich opowieści - mieszkali na Półwyspie Banksa, na wschodnim brzegu Wyspy Południowej.

Cokolwiek by sądzić na temat nieaustronezyjskiego substratu na terenie Oceanii, nie zostawił on znaczących śladów w kulturze jej rodzimych ludów. Tradycyjny model życia społecznego pod względem kulturowej stratygrafii wydaje się „płytki”. Model ten jest wszędzie podobny, wszędzie spotykamy też podobny sposób obróbki używanych od tysiącleci materiałów: drewna, kamieni i kości. Wszędzie dominuje rolnictwo (jamy, taro, bataty) połączone z ekstensywnym sposobem uprawy (sago) oraz z rybołówstwem, a także podobny zestaw zwierząt hodowlanych (świnia, kura). Szeroko rozpowszechniony jest ubiór z tapa, gdzie materiałem jest łyko z drzewa morwowego lub chlebowego. Oceaniczną specyfiką jest także tzw. tkactwo palcowe, polegające na splataniu nici i sznurów, $\mathrm{z}$ braku krosna, na palcach obu dłoni. Mieszkańcy wysp w tej sztuce doszli do wielkiej wprawy.

Owo podobieństwo nie rozciąga się wszakże na style budowania, gdzie, przeciwnie, panuje duża różnorodność. Dom bure z Fidżi, o dwuspadowym dachu typu kalenicowego, ale spadającym ukośnie również od strony szczytów, zupełnie nie przypomina fale ze względnie nieodległego przecież Samoa, który zbudowany jest na planie koła i ma dach stożkowaty. Okrągłe chaty budowano też na Nowej Kaledonii, tam jednak ściany tradycyjnego domu sporządza się z litej 
masy liści palmowych, tymczasem „ścianami” samoańskiego fale są jedynie ażurowe kraty zestawiane segmentami. Nowokaledoński dom ma szczyt w postaci zdobionego drewnianego pala, szczyt fale pozbawiony jest zdobienia.

„Domy mężczyzn" na Palau swoim charakterystycznym nachyleniem zdobionej ściany szczytowej przypominają arapeskie "domy obrzędu”, jednak taki sposób budowania bynajmniej nie jest rozpowszechniony ani na wyspach Mikronezji, ani też na Polinezji. Ten eklektyczny charakter architektury Oceanii jest zapewne wynikiem dużej ruchliwości pierwszych pokoleń nosicieli prototypów lokalnych kultur etnicznych. Żeglarze, przemierzając długą drogę, u mijanych ludów mieli możliwość podpatrzenia właściwych tamtym technik i stylów budowania, które według uznania zastosowali potem na nowym miejscu osiedlenia. Izolowane przez ocean atole i archipelagi pozostały każdy przy swoim stylu, tworząc w ten sposób opisaną wyżej estetyczną mozaikę. Wzajemna wymiana idei, jak widać, budownictwa lądowego tutaj nie dotyczyła.

Podobieństwa odnajdujemy głównie w kręgu wytworów związanych z morską komunikacją. Waka to nazwa łodzi, stosowanej powszechnie w całej Polinezji. Jej zasadnicze warianty znane są na całym obszarze Pacyfiku. Budowano je z jednego pnia drzewa, które wydrążano za pomocą siekierek. Szczególne znaczenie miały waka ama (tu i poniżej terminologia maoryska), czyli łodzie z pływakami, bocznymi wysięgnikami, dzięki którym pojazd wytrzymywał boczne uderzenia oceanicznych fal dochodzących nawet do dziesięciu metrów wysokości. Łódź mogła więc poruszać się po znacznych przestrzeniach, co umożliwiało jej użytkownikom penetrację innych archipelagów.

Do dalekich wypraw oceanicznych służyły waka tourua, dwukadłubowce o typie katamaranu. Waka taua, łodzie bojowe, miały do 40 metrów długości, ich budowa wymagała więc pozyskiwania specjalnych gatunków drzew. Mogło je obsadzić nawet do 80 wojowników, którzy, podobnie jak wikingowie, w trakcie podróży byli wioślarzami. W łodziach wojennych zwraca uwagę bogato zdobiony dziób. Stanowi go z reguły drewniana, ażurowa krata, rżnięta w abstrakcyjne, floresowate kształty. W łodziach Maorysów pod nią znajduje się rzeźba głowy wojownika z twarzą pokrytą tatuażem.

Nie wszystkie morskie waka posiadały napęd wiosłowy, wszystkie natomiast miały napęd żaglowy. Mniejsze waka tiwai służyły do łowienia ryb - poruszano się nimi po przybrzeżnych odcinkach morskich oraz (na Nowej Zelandii) w estuariach większych rzek.

Jeśli chodzi o estetykę, różnice stylów obszaru Pacyfiku mają charakter wtórny i ograniczony do niewielkiego terytorium. Ludy morskie nie stworzyły zjawiska, które by można określić mianem „,sztuki Polinezji” lub „sztuki Mikronezji”. Różnorodność ta obejmuje także mniejsze wyspy melanezyjskie. W rzeźbie i ozdobnej snycerce gdzieniegdzie brak przedstawień figuralnych, gdzie indziej takowe są podstawą tradycyjnej wytwórczości. W jednych miejscach zdobi się wyłącznie przedmioty związane z kultem religijnym (zwraca uwagę ornamentyka z Wysp Cooka i Tubuai), w innych - także przedmioty użytku codziennego. Na jednych archipelagach dominują przedstawienia ludzkie, na innych - ludzkie i zwierzęce 
(figury ptaków z Wysp Salomona), gdzie indziej brak jest w ogóle wizerunków zwierząt. Jaszczurka, która u Maorysów symbolizuje złego ducha (whiro) i nie jest przedstawiana na rzeźbach ani obrazach, na Vanuatu uznawana jest za ducha opiekuńczego. Dominują kolory czerwony, czarny i biały, uzyskiwane z glinki oraz sadzy, a także żółty, choć nie wszędzie się go używa (unikają go np. Maorysi). Są jednak regiony, takie jak melanezyjskie archipelagi Nowa Irlandia i położone bardziej w kierunku Polinezji Vanuatu, gdzie używa się prawie pełnej palety barw, włącznie z zieloną i niebieską.

Pod względem bogactwa form estetycznych można jednak do pewnego stopnia wyróżnić Melanezję i Polinezję. Estetyka Mikronezji jest nieco uboższa, co wynika zapewne z niewielkiej powierzchni stanowiących ją wysepek, a co za tym idzie, ograniczonego zestawu materiałów, z których tworzono zarówno narzędzia, jak i wykonywane nimi obiekty.

Osobnej uwagi wymaga kultura materialna maoryskiej Nowej Zelandii. Na obszarze pacyficznym jest to jedyny kraj, w którym - z racji rozmiarów jego terytorium - możliwe jest rozróżnienie na wybrzeże oraz interior, obszar wnętrza lądu, autonomiczny odeń pod względem fizjografii. Maorysi, którzy zamieszkują dziś zarówno wybrzeże, jak i środek Wyspy Północnej (Południowej nigdy do końca nie zasiedlono, gdyż panuje tam klimat zbyt zimny jak na wytrzymałość wychowanego w subtropikalnych warunkach Polinezyjczyka), pod względem archetypu kultury etnicznej pozostają jednak bez wyjątku ludem morza.

W porównaniu z przedstawionymi wcześniej autochtonicznymi społecznościami Australii i Nowej Gwinei, etnos Maorysów cechuje spolaryzowany układ stratygrafii. Dzielą się oni na plebs i arystokrację, przy czym ta ostatnia (rangatira) nadaje ton tradycyjnej kulturze. Przedstawiciele rangatira wywodzą się spośród naczelników legendarnych siedmiu łodzi (waka), których załogi zasiedliły obie wyspy nowozelandzkie. Termin waka określa także tożsamość całej wspólnoty. Aż do chwili obecnej wszyscy Maorysi uważają się za potomków załóg owych siedmiu łodzi - ich tradycyjny podział na plemiona (iwi) odpowiada mitycznemu podziałowi na załogi siedmiu waka.

Iwi, synonim plemienia, znaczy też dosłownie „kość”. Na iwi składają się rody hapu, które z kolei rozpadają się na pokolenia. Maorysi mówią o sobie Tangata whenua, co znaczy „ludzie kraju”. Mężczyzna tak się określający uważa się $\mathrm{w}$ pierwszym rzędzie za przedstawiciela relatywnie niewielkiego obszaru ziemi, który według tradycji jest "gniazdem rodowym" jego hapu. Odpowiedzialność za tę ziemię jest naczelnym obowiązkiem moralnym Maorysa. Drugi, równie silny imperatyw etyczny nakazuje mu opiekować się kobietami - żonami, matkami, siostrami - z którymi związało go pokrewieństwo, małżeństwo lub powinowactwo.

Kultura maoryska jest typową kulturą wojowników, gdzie naczelne miejsce zajmuje pamięć o przodkach, z czasem ujęta w ramy kultu. W rodzinach Maorysów zwraca uwagę więź przywiązania i szacunku, która łączy wnuki z pokoleniem dziadków. Ci bowiem przez opowieści uczą ich tradycji, którą nazywają ngakau Maori, czyli „,serce Maorysa”. Dzieci także dzisiaj, w epoce wszechobecnej 
telewizji, chętnie ich słuchają. Nawet w rodzinach, w których wnuki nie mówią już po maorysku, lecz po angielsku, mali słuchacze chłoną opowieść. Maoryskie pojęcie kaumatua oznacza jednocześnie „starca” i „nauczyciela”.

Wspólnym przodkiem plemienia jest wojownik, który zjednoczył wokół siebie pierwsze pokolenie wspólnoty. To od tych wodzów z mitycznej bohaterskiej epoki wywodzą się obecni rangatira. Z przynależnością do tej warstwy wiążą się pojęcia mana i tapu (tabu). Pierwsze oznacza moc odziedziczoną po przodkach, drugie - system nakazów i zakazów wynikający z przynależności do konkretnego rodu. Dzieci plebejuszy nie dziedziczą ani jednego, ani drugiego.

Kultura wojowniczych żeglarzy ma swoje zakorzenienie w mitach. Obok Tangaroa, boga oceanu, a także patrona żeglarzy i rybaków, w maoryskim panteonie naczelną rolę odgrywa Tu, bóg wojny. Etos wojownika jest tutaj elementem archetypu męskości.

Mężczyzna jest więc żeglarzem, wojownikiem, ale także artystą. Maoryska kosmologia łączy wszystkie trzy elementy. Męską rzeczą jest sprawne operowanie wiosłem oraz panowanie nad sterem, a także równie sprawne posługiwanie się taiaha, skrzyżowaniem włóczni z maczugą. Obok tych narzędzi powinien jednak z równą biegłością posługiwać się dłutem - nieważne czy bazaltowym, jak w przeszłości, czy też stalowym, jak obecnie. Za męską domenę uważane jest modelowanie twardego materiału, nad miękkimi (tkaniny itd.) mogą pracować kobiety. Dlatego w kosmologicznej skali wartości Maorysa rzeźba - i to najlepiej w twardym drewnie - będzie zawsze czymś lepszym, doskonalszym od obrazu lub malowanej tkaniny. Sztuki rzeźbienia (whakairo rakau) nauczył Maorysów bóg Rua, patron mężczyzn posługujących się dłutem. Twarze rzeźbionych postaci przedstawione są jako tatuowane, gdyż pokrywający całą twarz tatuaż składający się z wielu spiralnych motywów geometrycznych zawsze był tutaj domeną wodzów. Inni mężczyźni tatuowani byli skromniej, podobnie jak kobiety, które do dziś tatuują sobie tylko niewielki fragment twarzy łączący dolną wargę $\mathrm{z}$ brodą.

Na rzeźbionych i malowanych przedmiotach chętnie umieszcza się wizerunki przodków. Zwyczaju tego nie powinno się jednak utożsamiać z klasycznym kultem, gdyż wizerunkom tym nie oddaje się czci. Pełnią one rolę bardziej „praktyczną", przyciągając mana, magiczną siłę, do posiadaczy owych przedmiotów. Stosunkowo rzadko widujemy tu też wyobrażenia tradycyjnych bóstw. Anglosaski badacz zauważa trafnie:

Chociaż spotykamy tu posągi bogów, to jednak w porównaniu ze sztuką pozostałych regionów Polinezji sztuka Maorysów ma charakter wyraźnie powszedni, niekultowy; rzeźba $\mathrm{w}$ drewnie służy przede wszystkim odtworzeniu wizerunków przodków i jest podporządkowana architektonicznym wymogom domu ceremonii i domu, w którym gromadzone są zapasy (Barrow 1989: 244).

Etos wojownika i demiurga przynależy $\mathrm{w}$ pierwszym rzędzie warstwie wodzów grupujących się w klasie rangatira. To dla nich pierwotnie przeznaczone 
były charakterystyczne ozdoby wykonane z zielonego nefrytu lub zielonkawego, bardzo twardego kamienia pounamu, podobnego do jadeitu. Pierwsza z tych ozdób to manaia, wystylizowana do granic abstrakcji sylwetka podobna do syreny, ptaka czy też gryfa, zwinięta na kształt litery S. W wierzeniach Maorysów manaia oznacza posłańca, pośrednika między światem żywych i umarłych. Druga ozdoba, medalion hei tiki, przedstawia groteskową postać otyłego mężczyzny, którego stopy złączone są w okolicy krocza.

Współcześni Maorysi nie potrafią przekonująco objaśnić znaczenia obu tych symboli, jednak wiele wskazuje na to, że przywieźli je na Nową Zelandię z zachodu, z odległych Chin albo Indii (patrz też: Bolton 2013; Brunt 2013; Kjellgren 2007, 2014).

\section{Refleksje}

Zakreśliwszy powyższą panoramę, postawmy teraz pytania, od których zaczęliśmy nasz wywód: czy można mówić o odrębności kultury materialnej ludów Australii i Oceanii od innych obszarów kulturowych świata? Czy wyróżnikiem lokalnych kultur tego regionu pozostać miałby ocean, Pacyfik, którego ogrom w porównaniu z obszarami lądowymi w wyrazisty sposób zdominował sposób naszego myślenia o całości terytorium?

I tak, i nie. Części owych ludów, jak już wiemy, nie można zaliczyć do „ludów morskich" - chodzi tu o etnosy zamieszkujące wnętrze Australii i Nowej Gwinei. $\mathrm{W}$ ich kulturze materialnej brak jest odniesień do morza, rybołówstwa i żeglugi. Owe kultury lokalne cechuje jednak wysoki stopień izolacji względem sąsiadów. Wyrazem tej izolacji jest duża różnorodność miejscowych etnolektów, często niezrozumiałych nawet dla ludów mieszkających w bezpośredniej bliskości. Widać, że przez wieki, wręcz tysiąclecia, rozwijały się one osobno, redukując wzajemne kontakty do niezbędnego minimum.

Jednocześnie na tym samym obszarze australijskiego czy też nowogwinejskiego interioru uderza wysoki stopień podobieństwa kultury materialnej zbierackiej u Australijczyków, zaś rolniczej (o mało zaawansowanym stopniu rozwoju) u mieszkańców Nowej Gwinei. Tego podobieństwa nie należy traktować jako wynik oddziaływania konkretnych kręgów kulturowych, lecz efekt długotrwałego przystosowania do lokalnych warunków naturalnych oraz do położenia tych dwóch dużych lądów. W przypadku Nowej Gwinei o przyjęciu kultury rolnej zadecydowała bliskość obszaru Azji Południowo-Wschodniej. Jednak oddziaływania stamtąd miały ograniczoną moc i zasięg, dlatego na pewnym etapie prehistorii ustały. Odtąd Nowa Gwinea pod względem kulturowym rozwijała się osobno, podobnie jak Australia.

Spójrzmy teraz na podstawowe cechy typowo morskich kultur Oceanii. Pozornie wszystko wygląda tutaj inaczej. Odwrotnie niż w przypadku Australii oraz Nowej Gwinei języki, szczególnie te polinezyjskie, wykazują względne podobieństwo. Zupełnie inaczej wygląda też sytuacja lokalnych kultur 
materialnych, nierzadko w dużym stopniu zróżnicowanych, przynajmniej pod względem pewnych aspektów kultury, jak np. wygląd domów u Polinezyjczyków. Również tutaj - mimo kompletnie innych warunków naturalnych - należy stwierdzić wyraźny rys izolacji. Poszczególne archipelagi bywały zasiedlane i odtąd kultywowały własny sposób życia w oddzieleniu od innych, położonych daleko za wodą. Nawet w przypadku, gdy po kilku wiekach najeżdżane były przez kolejne ludy - co w sytuacji odległości, typowych dla Oceanu Spokojnego, należało raczej do rzadkości - nie dochodziło tutaj do znaczących fuzji kulturowych i jedna kultura zastępowała drugą. Wyspy archipelagów Melanezji i Polinezji okazały się zbyt małe, by mogły dokonać się na nich skomplikowane procesy etniczne.

Można dojść do wniosku, że ich wspólnym mianownikiem jest „insularność” miejscowych kultur. Ich charakter „wyspiarski”, ale nie w sensie geograficznym, lecz w wymiarze zamknięcia i odcięcia od poważnych i długotrwałych oddziaływań kulturowych z zewnątrz. Dotyczy to zarówno morskich etnosów Melanezji i Polinezji, jak i kultur interioru Australii oraz Nowej Gwinei.

Owa insularność sprawiła, że ludy Australii i Oceanii nie wytworzyły w swych dziejach cywilizacji trwałej i owocującej nowymi kulturowymi fenomenami. Tymczasem na każdym innym, zamieszkałym przez człowieka kontynencie cywilizacje takowe powstały i okazały się trwałym czynnikiem rozwoju przynajmniej do czasu, w którym uległy podbojowi z zewnątrz. O cywilizacjach epoki starożytności w Azji oraz Europie nie ma potrzeby się rozpisywać, Ameryka była obszarem rozkwitu cywilizacji Olmeków, Majów, Azteków czy Inków, nawet $\mathrm{w}$ niedocenianej, jak dotąd, przez historyków kultury Afryce powstały rodzime cywilizacje basenu Nigru. We wszystkich tych wypadkach chodzi o duże i zwarte obszary lądu stałego. Wzajemne kontakty morskie, tam gdzie do nich dochodziło (Azja i Europa), były tu swego rodzaju katalizatorem rozwoju. Jednak rozwój długotrwały i owocny zapewniony był tylko na obszarach, w których dochodzić mogło do lądowych kontaktów pomiędzy poszczególnymi, dwiema lub trzema cywilizacjami.

Takich warunków Australia i Oceania nie posiadały. Z przyczyn naturalnych nie mogło tutaj dochodzić do cywilizacyjnych impaktów, tarć, których owocem jest kulturowy rozwój zapewniający trwałość. Kultura Lapita, która była zjawiskiem pośrednim, etapem na drodze ku cywilizacyjnym formom, zanikła, gdyż pozbawiona była możliwości „zderzeń” z innymi kulturami o podobnym potencjale oraz stopniu rozwoju. Zwyciężyły stare formy plemiennej organizacji życia zbiorowości, ale trybalizm pod względem kulturowym tworzy obieg zamknięty, sam z siebie niezdolny do wytworzenia społecznie wyższych formacji.

Chociaż więc obszar Oceanu Spokojnego nie wytworzył własnej, wyrazistej estetyki, chociaż nie powstał tu względnie jednolity i rozpoznawalny "styl oceaniczny" wytworów kultury materialnej, jednak morze, oblewające brzegi jego rozrzuconych archipelagów, można uznać za szczególny obszar kulturowej łączności, a jednocześnie izolacji tradycyjnych etnosów Australii i Oceanii. 


\section{Literatura}

Bakke, M. (red.) (2004). Estetyka Aborygenów australijskich. Kraków: Universitas.

Barrow, T. (1989). Sztuka Maorysów z Nowej Zelandii. W: Sztuka Australii i Oceanii. Warszawa: Wydawnictwa Artystyczne i Filmowe.

Bęben, W. (2004). Mały świat wokót wulkanu: tradycyjne normy zwyczajowe w życiu wyspiarzy Biem w Papui Nowej Gwinei. Warszawa: Wydawnictwo DiG.

Bęben, W. (2012). Aborygeni, pierwsi nomadzi: życie i kultura. Gdańsk: Wydawnictwo Uniwersytetu Gdańskiego.

Bęben, W. (2015). Tańczący kanibale: wyspiarze Cieśniny Torresa. Gdańsk: Wydawnictwo Uniwersytetu Gdańskiego.

Bęben, W. (2016). Yamy, trucizna i duchy: Arapesze z Papui-Nowej Gwinei. Gdańsk: Wydawnictwo Uniwersytetu Gdańskiego.

Bęben, W. (2019). Dzieciństwo na Antypodach. Gdańsk: Wydawnictwo Uniwersytetu Gdańskiego.

Bednarowicz R. (2004). Sztuka aborygenów. Poznań: Galeriar.

Bolton, L., i in. (2013). Melanesia. Art and Encounter. Honolulu: University of Hawaii Press.

Borofsky, R. (2000). Remembrance of Pacific Pasts: An Invitation to Remake History. Honolulu: University of Hawaii Press.

Bowdler, S. (1977). The coastal colonisation of Australia. W: J. Allen, J. Golson, R. Jones, Sunda and Sahul: Prehistoric Studies in Southeast Asia, Melanesia and Australia. London: Academic Press.

Brunt, P., i in. (2013). Art in Oceania. A New History. New Haven: Yale University Press

Caruana, W. (1993). Aboriginal art. New York: Thames and Hudson.

Fischer, S.R. (2002). A history of the Pacific Islands. London: Palgrave Macmillan

Foley, W.A. (1986). The Papuan Languages of New Guinea. Cambridge: Cambridge University Press.

Fraser, D. (1976). Sztuka prymitywna, przeł. Michał Żułkoś-Rozmaryn. Warszawa: Wydawnictwa Artystyczne i Filmowe.

Genomic insights into the peopling of the Southwest Pacific (2016). Nature, 538 (praca zbiorowa).

Godlewski, A.L., Paluch, A. (1979). Ludy i kultury Oceanii: sesja poświęcona pamięci prof. dra A. Lecha Godlewskiego, Wroctaw, 27-28 XI 1976. Warszawa: PWN.

Hiscock, P. (2008). Archaeology of ancient Australia. London - New York : Routledge

Kjellgren, E. (2007). Oceania: Art of the Pacific Islands in The Metropolitan Museum of Art. New York: Metropolitan Museum of Art Publications.

Kjellgren, E. (2014). How to Read Oceanic Art. New York: Metropolitan Museum of Art Publications.

Meyer, A. JP (1995). Oceanic Art, Ozeanische Kunst, Art Océanien, zdjęcia O. Wipperfürth, vol. I, II. Köln: Könemann.

Morphy, H. (1998). Aboriginal art. New York: Phaidon.

Mountford, Ch.P. (1989). Sztuka pierwotnych mieszkańców Australii. W: Sztuka Australii i Oceanii. Warszawa: Wydawnictwa Artystyczne i Filmowe.

Murray, T., Leonards, St. (1988). Archaeology of Aboriginal Australia: A reader. Sydney: Allen \& Unwin.

Palmer, B. (ed.) (2018). The Languages and Linguistics of the New Guinea Area. A Comprehensive Guide. Berlin - Boston: De Gruyter Mouton. 
Paluch, A. (1983). Zagadnienie inercji tubylczych kultur australijskich. Acta Universitatis Wratislaviensis, Australia i wyspy Pacyfiku.

Posern-Zieliński, A. (1972). Polinezja - świat nieznany. Warszawa: Książka i Wiedza

Rosiński, F.M. (red.) (2001). Ludy i kultury Australii i Oceanii. Materiały z VII konferencji naukowej zorganizowanej we Wroctawiu w dniach 26 i 27 listopada 1996 r. przez Katedrę Etnologii Uniwersytetu Wrocławskiego. Wrocław: Wydawnictwo Katedry Etnologii Uniwersytetu Wrocławskiego.

Ross, M. (2005). Pronouns as a preliminary diagnostic for grouping Papuan languages. Canberra: ANU Research Publications.

Szyjewski, A. (1998). Religie Australii. Kraków: Nomos.

Tuzin, D.F. (2000). Social Complexity in the Making: A Case Study Among the Arapesh of New Guinea. London - New York: Routledge.

Tuzin, D.F. (2011). Echoes of the Tambaran: Masculinity, History and the Subject in the Work of Donald F. Tuzin. Sydney: ANU Press.

Watson, Ch. (1999). Touching the Land: Towards an aesthetic of Balgo contemporary painting, Canberra: ANU Research Publications.

Wierciński Andrzej (2010). Magia i religia. Szkice z antropologii religii. Kraków: Nomos.

\section{SUMMARY}

Traditional culture of the indigenous peoples of Australia and Oceania: Comparative perspective

In this text, I intend to demonstrate the commonalities and differences of traditional culture of the indigenous people of Australia and Oceania in the historical and comparative perspective, with special focus on the so-called material culture. This synthesis comprises the indigenous people inhabiting Australia, New Guinea and Oceania (Melanesia, Micronesia and Polynesia), followed by a reflection on whether there are cultural traits (especially in the material aspect) that are common to these three enormous cultural complexes.

Key words: indigenous people, material culture, Australia, New Guinea, Oceania 